\title{
Global lake responses to climate change
}

Article

Accepted Version

Woolway, R. I. ORCID: https://orcid.org/0000-0003-0498-7968, Kraemer, B. M. ORCID: https://orcid.org/0000-0002-33909005, Lenters, J. D., Merchant, C. J. ORCID:

https://orcid.org/0000-0003-4687-9850, O'Reilly, C. M. ORCID: https://orcid.org/0000-0001-9685-3697 and Sharma, S. (2020) Global lake responses to climate change. Nature Reviews Earth \& Environment, 1. pp. 388-403. ISSN 2662-138X doi: https://doi.org/10.1038/s43017-020-0067-5 Available at https://centaur.reading.ac.uk/91787/

It is advisable to refer to the publisher's version if you intend to cite from the work. See Guidance on citing.

Published version at: http://dx.doi.org/10.1038/s43017-020-0067-5

To link to this article DOI: http://dx.doi.org/10.1038/s43017-020-0067-5

Publisher: Nature

All outputs in CentAUR are protected by Intellectual Property Rights law, including copyright law. Copyright and IPR is retained by the creators or other copyright holders. Terms and conditions for use of this material are defined in the End User Agreement.

www.reading.ac.uk/centaur 
Central Archive at the University of Reading

Reading's research outputs online 
1 Global lake responses to climate change

2

3

4

5

6

7

8

9

10

11

12

13

14

15

16

17

18

19

20

21

22

23

24

25

26

27

28

29

30

31

32

33

34

35

36

37

38

39

R. Iestyn Woolway ${ }^{1,2 \dagger}$, Benjamin M. Kraemer ${ }^{3,11}$, John D. Lenters ${ }^{4,5,6,11}$, Christopher J. Merchant ${ }^{7,8,11}$, Catherine M. O’Reilly ${ }^{9,11}$, Sapna Sharma ${ }^{10,11}$

${ }^{1}$ Centre for Freshwater and Environmental Studies, Dundalk Institute of Technology, Dundalk, Ireland

${ }^{2}$ European Space Agency Climate Office, ECSAT, Harwell Campus, Didcot, Oxfordshire, UK

${ }^{3}$ Ecosystem Research Department, IGB Leibniz Institute of Freshwater Ecology and Inland Fisheries, Berlin, Germany

${ }^{4}$ Bureau of Water Quality, Wisconsin Department of Natural Resources, UW-Trout Lake Research Station, Boulder Junction, WI, USA

${ }^{5}$ Center for Limnology, University of Wisconsin-Madison, Madison, WI, USA

${ }^{6}$ Great Lakes Research Center, Michigan Technological University, Houghton, MI, USA

${ }^{7}$ Department of Meteorology, University of Reading, Reading, UK

${ }^{8}$ National Centre for Earth Observation, University of Reading, Reading, UK

${ }^{9}$ Department of Geography, Geology, and the Environment, Illinois State University, Normal, IL, USA

${ }^{10}$ Department of Biology, York University, Toronto, Ontario, Canada

${ }^{11}$ These authors are listed in alphabetical order because contributions were similar

†email: riwoolway@gmail.com

\section{Key points}

- Due to climate change, lakes are experiencing less ice cover, with over 100,000 lakes at risk of having ice-free winters if air temperatures increase by $4^{\circ} \mathrm{C}$. Ice duration has become 28 days shorter on average over the past 150 years for Northern Hemisphere lakes, with higher rates of change in recent decades.

- Lake surface water temperatures have increased worldwide at a global average rate of 0.34 ${ }^{\circ} \mathrm{C}$ decade ${ }^{-1}$, which is similar to or in excess of air temperature trends.

- Global annual mean lake evaporation rates are forecast to increase $16 \%$ by 2100 , with regional variations dependent on factors such as ice cover, stratification, wind speed and solar radiation.

- Global lake water storage is sensitive to climate change, but with substantial regional variability, and the magnitude of future changes in lake water storage remains uncertain.

- Decreases in winter ice cover and increasing lake surface water temperatures have led to mixing regime alterations that typically have resulted in less frequent mixing of lakes.

- Ecological consequences of these physical changes vary widely depending upon location, lake depth and area, mixing regime, and trophic status. 
Abstract

Climate change is one of the most severe threats to global lake ecosystems. Lake surface conditions, such as ice cover, surface temperature, evaporation and water level respond dramatically to climate change, as observed in recent decades. In this Review, we discuss physical lake variables and their responses to climate change. Decreases in winter ice cover and increases in lake surface temperature modify lake mixing regimes and accelerate lake evaporation. Where not balanced by increased mean precipitation or inflow, higher evaporation rates will favour a decrease in lake level and surface water extent. Together with increases in extreme precipitation events, these lake responses to climate change will impact lake ecosystems, changing water quantity and quality, food provisioning, recreational opportunities, and transportation. Future research opportunities, including enhanced observation of lake variables from space (particularly for small water bodies), improved in-situ lake monitoring, and the development of advanced modelling techniques to predict lake processes, will improve our global understanding of lake responses to a changing climate.

\section{[H1] Introduction}

Lakes are a critical natural resource that are sensitive to changes in climate. There are more than 100 million lakes globally ${ }^{1}$, holding $87 \%$ of Earth's liquid surface freshwater ${ }^{2}$. Lakes support a global heritage of biodiversity ${ }^{3}$ and provide key ecosystem services ${ }^{4}$; as such, they are included in the United Nations' Sustainable Development Goals committed to water resources (Goal \#6) and the impacts of climate change (Goal \#13) ${ }^{5}$. Lakes are also key indicators of local and regional watershed changes, making lakes useful for detecting Earth's response to climate change ${ }^{6}$. Specifically, variables such as lake surface temperature, water level and extent, ice cover, and lake colour are recognised by the Global Climate Observing System (GCOS) as Essential Climate Variables (ECVs) because they contribute critically to the characterization of Earth's climate. The scientific value of lake research makes it an essential component of the United Nations Framework Convention on Climate Change (UNFCCC) and the Intergovernmental Panel on Climate Change (IPCC).

Lakes are already responding rapidly to climate change. Some of the most pervasive and concerning physical consequences of climate change on lakes are the loss of ice cover ${ }^{7}$, changes in evaporation and water budgets ${ }^{8,9}$, warming surface water temperature ${ }^{10}$, and alterations in mixing regimes ${ }^{11}$. These lake variables interact with one another (Fig. 1), complicating our ability to predict lake physical responses to climatic variations. For example, changes in ice cover and water temperature modify (and are influenced by) evaporation rates $^{9}$, which can subsequently alter lake levels and surface water extent ${ }^{12}$. In the absence of precipitation changes, one of the effects of reduced ice cover, higher surface water temperatures, and increased lake evaporation rates could be reductions in lake level and extent. However, land surface runoff and direct precipitation to the lake also affect lake level and extent, which are subject to climatic variations across the lake catchment, reinforcing or even offsetting the effects mediated by evaporation. Such sensitive balances between climatically driven factors lead to spatially variable outcomes for lake-climate interactions that require further elucidation to understand and predict. 
In this Review, we summarize the responses of key physical lake variables and processes to global climate change, including ice cover, surface water temperature, evaporation, water levels, and mixing regimes, and outline their ecological consequences (Fig. 1). We also identify research needs for improving our global understanding of lake responses to climatic variability and change, including enhancing satellite observations and in-situ technology for monitoring both small lakes (which dominate the global lake distribution) and large lakes with high spatial heterogeneity, developing global-scale modelling techniques to better predict lake responses under climate change, and establishing collaborations between limnologists and remote sensing scientists.

\section{[H1] Decreasing lake ice}

Lake ice phenology - the timing of ice freeze and breakup - is a sensitive indicator of climate ${ }^{13,14}$. Lake ice formation is dictated by the surface energy balance and mediated by air temperature, lake morphology, wind-induced mixing, and other meteorological, morphometric, and hydrologic influences ${ }^{15}$. For example, heat loss from the lake surface during the ice-formation process occurs primarily through outgoing longwave radiation and sensible and latent heat flux ${ }^{16}$. As such, initial ice formation often occurs at night under cold, calm, clear-sky conditions. However, strong cooling and deep mixing is often required to "prime" the lake prior to initial ice formation at the surface, typically through cold, dry, wind events that lead to strong sensible and evaporative heat loss ${ }^{17}$.

Lake depth also modulates ice formation, thickness, and spatial coverage, as deeper lakes take longer to cool in autumn ${ }^{7}, 15,18$. Air temperatures in autumn need to be below $0^{\circ} \mathrm{C}$ for a longer period of time before deeper lakes freeze ${ }^{19}$, and deep lakes are more sensitive to experiencing intermittent winter ice cover (that is, not freezing every winter) ${ }^{7}$. Larger lakes with a longer fetch [G] tend to also freeze later, as they are more sensitive to increased wind action breaking up the initial skim of ice on the lake surface ${ }^{20,21}$. Thus, under scenarios of climate warming, deeper lakes with larger fetch are expected to be more susceptible to losing ice cover than shallower lakes within the same region ${ }^{7,21}$.

The timing of lake ice breakup is generally governed by air temperature and its attendant effects on other components of the surface energy balance, primarily net radiation ${ }^{16,22,23}$. Warmer air temperature in the range of weeks to months prior to ice breakup is usually the most important atmospheric driver of ice breakup, in part due to its additive effects on sensible heat flux, downward longwave radiation, snow and ice albedo [G], and thus the total amount of absorbed longwave and shortwave radiation at the lake surface ${ }^{16,22,24}$. The importance of air temperature is seen in Alaskan lakes, for example, where the date of the $0{ }^{\circ} \mathrm{C}$ air temperature isotherm, together with lake area, can explain over $80 \%$ of the variation in ice breakup dates ${ }^{25}$. Warmer late winter and early spring temperatures are also correlated with earlier ice breakup in other locations ${ }^{26,27}$, with lakes in more southern regions experiencing the highest rates of change ${ }^{18,24}$.

Snow depth, shortwave radiation, and wind explain additional variation in breakup dates ${ }^{15,16,18,28}$. Greater snow cover can delay ice breakup through its higher albedo and greater insulation during spring, as well as the additional contribution of snowpack to lake ice thickness throughout the winter ${ }^{16}$. However, seasonal timing is also important, since insulating snow cover in early winter 
can slow the rate of ice formation. For example, in Lake Baikal, cold winters with low snowfall and early ice formation tend to correspond to thicker ice cover and later ice breakup ${ }^{29}$. In contrast, high snowfall acts as a reflective and insulating layer for lakes in Estonia, corresponding to a later ice breakup ${ }^{19}$. In addition, stronger incoming solar radiation facilitates earlier ice melt, and the amount of solar radiation absorbed within the lake is governed in part by the amount of snow cover on the ice and the light transmission through both snow and ice ${ }^{15,28,30}$. With continued climate warming, lake ice breakup is expected to advance further. For example, ice breakup is projected to be 10-25 days earlier in the Canadian Arctic $^{31}$ and 10-30 days earlier across other locations within the Northern Hemisphere ${ }^{32}$ by mid-century, compared to the late $20^{\text {th }}$ century.

Records of lake ice freeze and breakup reveal that lakes in the Northern Hemisphere are experiencing earlier ice breakup, later ice freeze-up and shorter ice duration ${ }^{14,18,26}$, and, in some years, some lakes do not freeze at all ${ }^{7,13,33}$. Magnuson et al., (2000) calculated trends in ice freeze dates, ice breakup dates, and ice duration from 1855 to 1995 for 20 spatially and morphologically heterogeneous lakes distributed around the Northern Hemisphere. In this Review, we updated the ice phenology records for 19 of these 20 lakes by an additional 24 years, to 2019 (Fig. 2a and b). The trends in freeze date are 2.4 times faster between $\sim 1855-2019$ than 1855-1995, such that ice formation is 11.6 days later per century, compared to 4.8 days later per century as calculated by ref. 14. Similarly, trends in break-up dates are now 1.3 times faster in the updated time series, and ice break-up is 8.1 days earlier per century, compared to 6.2 days earlier per century as previously calculated ${ }^{14}$, and ice duration is now 19 days shorter per century on average. Indeed, ice cover is being lost at a progressively faster rate, as these lakes have lost an additional week of ice cover in just the past $\sim 25$ years alone (Fig. 2a and b), due to both earlier ice breakup and later ice freeze among lakes across the Northern Hemisphere. In addition, if air temperatures warm globally by as much as $4.5^{\circ} \mathrm{C}$, the number of lakes in the Northern Hemisphere that experience intermittent winter ice cover are projected to rise from the current 15,000 lakes to up to 90,000 (ref. 7) (Fig. 2c).

In summary, as climate changes, we predict that lake ice will be increasingly lost. Ice phenology in some regions is changing non-linearly (Fig. 2), with faster rates of lake warming in response to climatic change and phase switches of large-scale climate oscillations such as El Niño Southern Oscillation (ENSO), the North Atlantic Oscillation (NAO), and Pacific Decadal Oscillation (PDO) $34,35,36$. Increased greenhouse gas emissions and warming temperatures have been contributing to shorter ENSO and NAO cycles since the latter half of the $20^{\text {th }}$ century ${ }^{37,38}$, directly impacting ice breakup and freeze dates ${ }^{33}$. However, the non-linear interactions of ever-changing large-scale climate oscillations with one another, in addition to climate complicates our ability to forecast ice phenology with a high degree of confidence ${ }^{39}$.

\section{[H1] Warming lake surface waters}

Lake surface water temperature (LSWT), an indicator of climate change, is influenced by climatic and in-lake drivers that contribute to the lake surface energy budget (Fig. 3). Notable drivers include the amount of incoming shortwave and longwave radiation, the proportion of solar irradiance absorbed at the lake surface (albedo), the advection [G] and storage of heat within the lake, and the loss of heat at the air-water interface through outgoing longwave radiation and 
turbulent fluxes of sensible and latent heat. These drivers are affected by many climatic variables, including cloud cover, over-lake wind speed, atmospheric humidity, and air temperature ${ }^{40}$, as well as two critical lake surface parameters - LSWT and ice cover. Thus, changes in any of the aforementioned climatic variables can influence LSWT (and ice cover) through multiple feedbacks in the surface energy balance (Fig. 3).

For example, the feedback of evaporative cooling leads to a fundamental response of LSWT to a warming climate, namely that, absent other inputs of energy, lake surfaces should warm at a slower rate than air temperature alone ${ }^{9,41}$. However, there are many observations of LSWT increasing more rapidly than local air temperature, often due to earlier stratification ${ }^{42,43}$, increasing incoming solar radiation ${ }^{10,44,45}$, or declining near-surface wind speed ${ }^{46}$, which affects turbulent heat fluxes, vertical mixing and heat storage. Moreover, lake-specific factors complicate some of these expected thermal responses to climatic variations. Specifically, changes in river discharge regimes ${ }^{47}$ and water clarity ${ }^{48,49}$ can have a considerable influence on lake surface temperature, amplifying or dampening surface warming rates.

A global synthesis of warm-season LSWT observations demonstrated that lakes worldwide have warmed at an average rate of $0.34^{\circ} \mathrm{C} \mathrm{decade}^{-1}$ from 1985 to 2009 (ref. 10). Generally, lakes in regions with cold winters (mean air temperature $<-0.4^{\circ} \mathrm{C}$ ) are warming more rapidly than lakes in regions with warm winters ${ }^{10}$, partially reflecting the amplified increase in air temperature in polar and high-latitude regions ${ }^{50,51}$. However, cold-region lakes also show observed trends in warmseason LSWTs that are comparable to or even in excess of air temperature trends ${ }^{9,42,52}$. The trends suggest a response to earlier stratification or an additional source of energy for the lakes, such as greater absorption of solar radiation ${ }^{44}$, with contributions in some cases due to reduced ice cover ${ }^{42}$, ${ }^{45}$ or reduced snowfall and snowmelt, resulting in more available energy to warm surface waters or increase evaporation rates 9 .

Whereas ice-albedo feedbacks in driving LSWT trends are important for high-latitude snow and ice processes ${ }^{53,54}$, their effects are more muted in mid-latitude lakes that experience earlier ice breakup ${ }^{45}$. In part the muted response is due to the loss of ice's insulating properties at ice-off (the capping of sensible and latent heat fluxes) ${ }^{55}$. Specifically, although a reduction in ice cover can result in a lower surface albedo and ultimately warm the lake surface, it can also promote heat loss from the lake to the atmosphere, leading to a cooling effect ${ }^{45}$. Thus, the importance of ice-albedo feedbacks remains in question and is likely to be significant for mostly high-latitude and alpine lakes that have prolonged ice-covered seasons ${ }^{9}$.

For many mid-latitude dimictic lakes (particularly deep ones such as the Laurentian Great Lakes), it is becoming apparent that the amplified warm-season LSWT trends are primarily the result of earlier stratification and a prolonged summer stratified period ${ }^{42,43,56}$. Specifically, LSWT increases more rapidly due to smaller volumes of water participating directly in the air-water surface heat exchange. Therefore, an earlier stratification onset and thus prolonged presence of the shallow upper mixed layer can result in higher warm-season LSWTs than would be expected from changes in air temperature alone ${ }^{42,43}$. However, the effect of stratification onset on warm-season LSWT can 
vary significantly among and within lakes ${ }^{43,57}$, and often has the largest effect on lakes situated at high latitude and/or high elevation, as well as in deep lakes (or the deepest regions within large lakes), such as Lakes Superior (USA and Canada) and Tahoe (USA), and Lake Ladoga (Russia).

Most global studies of LSWT responses to climate change focus on summer observations in temperate and high latitude regions and winter observations in the tropics, partly because of obscuration of satellite retrievals by tropical clouds during summer or because a large proportion of lakes in northern latitudes are frozen during winter. We could therefore be missing important changes that are taking place in other seasons ${ }^{44,58,59,60}$, which merits future study.

\section{[H1] Increasing lake evaporation}

Evaporation (latent heat flux) of surface water directly and substantially modifies the hydrologic, chemical and energy budgets of lakes, making it an important physical control on lake ecosystems ${ }^{41,61,62}$. In addition to removing freshwater, the cooling effect of latent heat flux through evaporation is central to the modification of LSWT, ice formation, stratification ${ }^{17}, 56$, vertical mixing and gas fluxes ${ }^{55,63}$. Importantly, lake evaporation also influences lake level and extent ${ }^{64}$, experiences two-way feedbacks between salinity and evaporation rates ${ }^{62,}{ }^{65}$, and even affects regional climate itself (such as lake-effect clouds and precipitation) ${ }^{66}$.

233

A thorough understanding of lake evaporation and its underlying physical drivers is essential for predicting the response of lake ecosystems to climate change ${ }^{67}$. Evaporation is energy-driven and consumes approximately $82 \%$ of the global available radiative energy at the earth's surface ${ }^{68,69}$. However, the diffusive nature of evaporation lends itself to mass transfer (or "bulk aerodynamic") formulations, wherein the open-water evaporation rate is simply proportional to the near-surface vapor pressure gradient and various functions of wind speed and atmospheric stability ${ }^{70,}{ }^{71}$. Although the most direct atmospheric drivers of lake evaporation are arguably wind speed and absolute humidity ${ }^{72}$, prediction of the vapor pressure gradient within models also requires knowledge of LSWT and ice to calculate the saturation vapor pressure at the lake surface ${ }^{67}$. As a result, other drivers of LSWT, ice cover, and lake evaporation must also be considered ${ }^{9,41,55}$, including air temperature (through sensible heat flux and Bowen ratio [G]), incoming solar and longwave radiation (such as effects of cloud cover), advective sources of heat (snowmelt and groundwater, for example), and changes in lake heat storage (such as through whole-lake cooling or changes in stratification and mixing). The energy available for evaporation is also modulated by the amount of emitted and reflected radiation from the lake surface, which is primarily dictated by LSWT and shortwave albedo, respectively. Finally, the timing, intensity, and overall volumetric flux of lake evaporation can also be modified by numerous lake-specific and landscape variables such as water clarity, lake area, and effects of wind sheltering ${ }^{64,73,74}$.

The response of lake evaporation to climate change is likely to be spatially variable due to these complex, interacting factors, but a global-mean annual lake evaporation increase of $16 \%$ is expected by 2100 , relative to 2006-2015 (refs 9,67). The largest increases in annual evaporation are expected at low latitudes (annual changes of $\sim 210 \mathrm{~mm} \mathrm{y}^{-1}$ ), where evaporation rates are already high $\left(1622 \mathrm{~mm} \mathrm{y}^{-1} ; 2006-2015 \text { annual mean for lakes between } 30^{\circ} \mathrm{S} \text { and } 30^{\circ} \mathrm{N}\right)^{9}$. The evaporation 
increase for low-latitude lakes is primarily a surface energy balance response to increased air temperatures and downward longwave radiation, which also drive an increase in LSWT. Relative to air temperature, however, the increase in LSWT is muted by the loss of additional energy to evaporative cooling and emitted longwave radiation, leading to a weakened lake-air temperature gradient, reduced sensible heat flux, and $\sim 27 \%$ smaller Bowen ratios by 2100 , on average (particularly in tropical, temperate, and arid regions) ${ }^{9}$ (Fig. 4).

264

In addition to the previously discussed factors, annual lake evaporation in cold and polar regions is also influenced by reduced ice and snow cover during warmer winters, as well as earlier summer stratification $35,45,56$, with global-mean lake surface albedo projected to decline by $\sim 15 \%$ by the year 2100 (ref. 9). These effects lead to higher evaporation rates through the additional absorption of solar radiation ${ }^{9}$ and a greater concentration of available energy in the upper-mixed layer during summer ${ }^{42,45}$, which can be especially pronounced for deep, dimictic lakes, even those with limited ice cover.

Although changes in longwave radiation, Bowen ratio, ice cover, and stratification are generally expected to dominate the long-term response of lake evaporation to climate change ${ }^{9}$, additional factors must also be considered, particularly on shorter timescales. For example, decadal-scale global and regional changes in incident solar radiation due to variations in cloud cover and aerosols (often referred to as solar brightening [G] or dimming [G]; ref. 75) contribute to trends in pan evaporation ${ }^{75,76}$. Similar to evaporation pans, lakes are energy-limited systems, so some lakes could see increased evaporation in response to solar brightening trends, particularly in light of the changes observed in LSWT $^{44,45}$. While such variations could continue in the future at decadal timescales, widespread long-term trends in solar radiation are not generally expected ${ }^{9}, 44,45,75$. Similarly, downward trends in wind speed and declines in evaporative demand have also been noted ${ }^{73}$, but other studies have observed a recent reversal of that global trend ${ }^{77}$ or even an upward trend in regional wind speed ${ }^{78}$. Thus, solar- and wind-induced trends in lake evaporation are likely to be highly localized and variable in the short term, and smaller in magnitude on longer timescales. Changes in humidity could further influence evaporation trends, and global atmospheric specific humidity is projected to increase in the future ${ }^{79}$. A more humid atmosphere, however, is not likely to counteract increasing evaporative demand over rapidly warming land surfaces ${ }^{80}$ and lakes ${ }^{9,10}$.

Finally, it is important to note that lake evaporation is often highly episodic ${ }^{41,72}$, and that interannual changes in synoptic weather variability - such as the frequency of cold fronts - are known to significantly influence LSWT, lake evaporation, sensible heat flux, and the depth and intensity of vertical mixing ${ }^{63,81}$. Thus, accurate projections of the response of lake evaporation to climate change will need to account not only for trends in the mean climate, but also changes in variability.

\section{[H1] Wetting and drying trends}

Climate-driven variability in lake water storage is the result of changing water availability within a lake's watershed, which is fundamentally a tradeoff among precipitation $(\mathrm{P})$, evaporative water loss, and changes in terrestrial water storage ${ }^{82}$. This tradeoff includes consideration of land-surface 
water balance processes such as evapotranspiration (ET) [G], snow and soil water storage, and runoff; and in-lake processes such as surface and groundwater outflow and open-water evaporation (a component of ET). Except in certain instances (such as inputs of glacial meltwater), changes in land surface water storage are minimal on climatic timescales, resulting in a long-term balance between P - ET and total runoff [G]. As such, understanding climate change impacts on water availability requires a joint examination of trends in both $\mathrm{P}$ and $\mathrm{ET}$, as well as various indices of "wetting" and "drying," such as P $-\mathrm{ET}^{83}$, the Palmer Drought Severity Index (PDSI) ${ }^{84}$, and the aridity index ${ }^{85}$. It is also important to distinguish between lakes in wet and dry regions when considering the potential impacts of climate change, since wetting and drying trends have been shown to differ for such regions ${ }^{83}$.

Although there remains little consensus as to climate-induced trends in annual mean precipitation at local to regional scales ${ }^{86}$, some patterns have begun to emerge as it relates to changes in extreme precipitation, global-mean $\mathrm{P}$ and ET, and regional patterns of wetting and drying. Both $\mathrm{P}$ and ET are projected to increase globally as the climate warms and the hydrologic cycle intensifies ${ }^{79}$. Regional variability in P and ET trends are also expected ${ }^{64,79}$, with the increase in ET predicted to be largest for energy-limited lakes and oceans. Global land surfaces are anticipated to see a more modest increase in ET due to additional constraints from water limitation ${ }^{79}$ and potential increases in aridity at regional scales ${ }^{80}$.

The "dry gets drier, wet gets wetter" (DDWW) paradigm has often been demonstrated in future projections of $\mathrm{P}-\mathrm{ET}$ over broad oceanic regions ${ }^{83,84,86,87}$, albeit with less applicability to land surfaces and smaller spatial scales ${ }^{85,88,89}$. Nonetheless, some poleward expansion of subtropical dry zones has been projected to occur by the end of the $21^{\text {st }}$ century ${ }^{90}$, with overall global drylands expected to grow in area by $11-23 \%$ and warm at twice the rate of humid regions ${ }^{91}$. There is also evidence for a "wet gets wetter" signal over water-sufficient lands, including eastern North America, northern Canada, Europe, and Asia, and in tropical convergence zones and monsoon regions $^{85,92,93,94}$. The distinction between wet and dry regions extends to lake evaporation, which is influenced by regional climate in a fashion similar to evaporation pans. Specifically, local-scale variations in precipitation, terrestrial ET, atmospheric humidity, and cloud cover (particularly in water-limited regions) are known to influence pan evaporation rates via the complementary relationship ${ }^{95}$, such that variations in precipitation and pan evaporation often show an inverse relationship. Evidence of similar behavior for lakes is supported by regional observations of enhanced lake evaporation ( $20 \%$, relative to precipitation anomalies) during years with low precipitation $^{82}$.

In contrast to the DDWW paradigm that suggests differing regional trends in $\mathrm{P}-\mathrm{ET}$, increases in extreme precipitation are observed and expected for both wet and dry regions, though with significant spatial heterogeneity ${ }^{86}$. These changes include global increases in the observed number of wet days, number of heavy precipitation events, and annual maximum daily precipitation ${ }^{94,96}$. For example, annual maximum daily precipitation in both wet and dry regions was found to increase over a 60 -year period (1951-2010) at a rate of 1-2\% per decade ${ }^{86}$. Integrated over longer timescales, anomalously high precipitation from months to decades can also lead to significant 
hydrologic impacts on even the largest of lake systems, including regional flooding and rapid lake level rise ${ }^{97}$, and increased delivery of nutrients, sediments, pollutants, and dissolved organic matter to lakes.

\section{[H1] Changing lake water storage}

349

The amount of water stored in specific lakes may increase, decrease, or experience no substantial cumulative change in a warming climate ${ }^{8,12,98,99}$. Indeed, although the global hydrologic cycle is sensitive to climate change, the actual magnitude of hydrologic changes that can be assuredly attributed to climate change remains uncertain, particularly given the key impact of human water withdrawal ${ }^{100}$.

The attribution of water storage variation in lakes to climate change is facilitated when variations occur coherently across many lakes within broad geographic regions ${ }^{82}$, preferably absent of other anthropogenic hydrologic influences. For instance, water storage increases on the Tibetan Plateau (Fig. 5) have been attributed to long-term changes in glacier melt, precipitation, and runoff, in part as a result of climate change ${ }^{101,102,103}$. While most lakes on the Tibetan Plateau are increasing in size in response to these changes, there are exceptions due to local factors (see Orba and La-ang in Fig. 5). Nevertheless, these increases can be attributed to climate change, as they are corroborated by half-century old ground survey data ${ }^{104}$ and recent observations from the GRACE satellite mission $^{8,105}$, and because there are minimal irrigated agriculture operations or water diversions that could confound the trend ${ }^{8}$.

Climate change can also affect water storage in thermokarst lakes [G]. Initial permafrost thaw typically leads to thermokarst lake water storage increases ${ }^{106}$, which can be enhanced by local increases in precipitation ${ }^{8}$. However, the initial lake expansion often gives way to lake drainage as the surrounding permafrost degrades further with warming ${ }^{107}$. The temporal pattern of lake formation followed by lake drainage is observed in the Arctic, where lake area has increased in regions with continuous permafrost and decreased in regions where permafrost is thinner and less contiguous $^{106}$. These substantial water storage changes in thermokarst lakes and glacier-fed lakes represent the potentially severe hydrologic modifications that can result from climate change.

Despite the pronounced effects of climate change on lake water storage in specific regions, resolving the global-scale effects remains challenging, in part due to a lack of consensus about the magnitude of water flux changes that can be attributed to climate change versus other drivers of change ${ }^{97,100}$. For example, from 1984 to $2015,90,000 \mathrm{~km}^{2}$ of permanent surface water disappeared globally, while $184,000 \mathrm{~km}^{2}$ of lake surface area formed elsewhere ${ }^{12}$. Most of these changes are thought to be attributable to background climate variability, water extractions and reservoir filling, rather than climate change ${ }^{12}$. In a classic example, the two main inflowing rivers to the Aral Sea were diverted in the 1970's in an attempt to irrigate cotton plantations in Central Asian deserts ${ }^{108}$, leading to a 37,000 $\mathrm{km}^{2}$ loss of Aral Sea surface area from 1984 to 2015 (ref. 12). Thus, although climate change might have contributed to the reduction in size of the Aral Sea ${ }^{109}$ and lakes such as Lake Poopó in Bolivia, such attributions remain controversial ${ }^{108,110}$. 
Even in remote lakes that are not directly influenced by human activity, the effects of climate change on lake water budgets are often masked by the effects of background climate variability and atmospheric teleconnections such as $\mathrm{ENSO}^{111}$, the $\mathrm{PDO}^{112}$, the $\mathrm{NAO}^{113}$, and the Indian Ocean Dipole $^{114}$. Many of these oscillations are multi-decadal, making it especially difficult to disentangle them from the effects of climate change ${ }^{100}$. For example, recent (2002-2016) changes in terrestrial water storage in Australia and Sub-Saharan Africa have been attributed to the passage of natural drought and precipitation cycles, not climate change ${ }^{8}$. The complexities of lake water storage responses to climate change and the challenges associated with its detection and attribution are reflected in the ongoing debate about the influence of climate change effects on lake water storage $^{115,116}$.

Lake water storage projections are limited primarily by the absence of reliable, long-term, homogenous and spatially resolved hydrologic observations necessary for building lake water budgets and for assessing the validity of climate models ${ }^{100}$. This uncertainty is reflected in the widely divergent projections for lake water storage responses of individual lakes to future climate changes ${ }^{117,118}$, which vary based on the emissions scenario and the uncertainty in the simulated effects of climate change on the regional hydrology ${ }^{98,119}$. Selecting models that perform well in cross validation often does little to reduce water storage projection uncertainty due to differences in the future emission scenarios and variation across model simulations ${ }^{117}$. This wide range of potential changes makes it difficult to manage lakes in the context of anticipated future patterns of lake water storage. Until the influence of climate change on all water fluxes (precipitation, ET, runoff) relevant to specific lake water budgets can be adequately resolved, the magnitude of climate change effects on global lake water storage will remain highly uncertain, particularly in the presence of interannual climate variability.

\section{[H1] Altered lake mixing regimes}

The lake energy balance and associated surface variables (such as ice cover and LSWT), in addition to lake morphometry have a considerable influence on the physical environment of lakes, especially their seasonal mixing regimes ${ }^{120}$ (Box 1). In response to climate-induced variations in these lake surface conditions, the mixing regimes of lakes are projected to change through time ${ }^{11,121,122}$, with numerous consequential implications for lake ecosystems.

One of the most commonly projected alterations in lake mixing regimes during the $21^{\text {st }}$ century is a change from dimictic to monomictic conditions, with $\sim 17 \%$ of all lakes likely to experience this mixing regime alteration by 2080-2099 (ref. 11; Fig. 6). Specifically, warming winters, a loss of ice cover, and warmer winter surface waters $\left(\sim 4^{\circ} \mathrm{C}\right.$; roughly the temperature of maximum density of freshwater) will result in lakes no longer typically experiencing an inversely stratified winter period, thus remaining vertically mixed from autumn (following autumnal mixing) until stratification onset in spring. Given current projections of lake ice loss ${ }^{7}$, this type of mixing regime alteration is expected to be particularly common in deep, alpine lakes such as Mondsee, Austria ${ }^{123}$. The influence of ice cover loss on lake mixing regimes is also evident in high Artic lakes, which are typically perennially ice covered. Specifically, a warming climate has resulted in many Arctic 
lakes now experiencing seasonal ice cover, and thus mixing vertically during the warmest months ${ }^{124}$.

Another commonly identified alteration in lake mixing regimes is a change from monomictic to oligomictic and/or meromictic ${ }^{11}$ (Fig. 6). An increase in winter LSWT is key a driver of change from monomictic to oligomictic and/or meromictic conditions ${ }^{125}$. In particular, if the surface temperature of deep lakes no longer falls to $4{ }^{\circ} \mathrm{C}$, stratification can persist from one summer to the next without interruption, inhibiting complete turnover. There is some evidence that this could, indeed, already be taking place, with deeply penetrative mixing being suppressed in some traditionally monomictic lakes (such as Lake Zurich, Switzerland) during increasingly mild winters ${ }^{126}$. Furthermore, lakes that are currently classified as oligomictic (such as Lakes Garda and Como, Italy) are very likely to transition to the meromictic class under future climate conditions due to warming surface waters during winter ${ }^{11}$.

Lakes most susceptible to mixing regime alterations are those that are "marginal", historically transitioning between two mixing classes and often experiencing anomalous mixing behavior relative to their dominant mixing classification (defined as experiencing at least three years of anomalous mixing regimes during a 20 -year period; ref. 11). For example, a dimictic lake that does not freeze during a particularly warm winter and thus might experience a monomictic year, such as in Lakes Vänern and Vättern in Sweden ${ }^{127}$, will likely experience a mixing regime alteration in the future. Also, polymictic lakes that can develop prolonged stratification during summer in some warm or calm years are particularly vulnerable to experiencing a mixing regime alteration (such as becoming monomictic) under climate change ${ }^{128}$.

The mixing regimes of marginal lakes have also been described as being very sensitive to changes in water clarity ${ }^{122,129}$. Specifically, a "browning" [G] of lake surface waters (resulting in a decrease in water transparency), due mainly to terrestrial inputs of dissolved organic matter ${ }^{130,131,132}$, affects the depth at which shortwave radiation is absorbed within a lake. The browning has a profound influence on the vertical thermal structure ${ }^{49}$ and can, for example, determine whether a lake mixes regularly or stratifies continuously throughout the summer period ${ }^{129}$. The interactions among decreasing water transparency, vertical thermal structure, and altered lake mixing regimes are expected to be most important in historically clearer lakes ${ }^{49,122}$.

While the majority of previous studies have demonstrated that climate change is likely to shift mixing regimes to the right along the polymictic-dimictic-monomictic-oligomictic-meromictic continuum (Fig. 6), some lakes will not follow the expected directional change. For example, some are projected to experience fewer continuous periods of stratification due to a local increase in near-surface wind speed caused by, for instance, a recovery from atmospheric stilling ${ }^{77}$. Specifically, an increase in wind mixing could push a lake to a less stable regime and ultimately result in a lake transitioning from a dimictic to a polymictic mixing class ${ }^{11}$. There are also many examples of saline lakes that have experienced a relatively unexpected change in their mixing regime due to climatic warming. For example, the extensively studied meromictic Lake Shira (Russia) has recently shifted from a meromictic to a dimictic mixing class due to a decrease in 
winter ice cover, which resulted in less salt exclusion and thus weaker stratification, thereby allowing the lake to overturn ${ }^{133}$. Overall, the influence of climate change on lake mixing regimes is complex, but we are beginning to understand the global drivers of historic change and have projected mixing regime alterations in many lakes during the $21^{\text {st }}$ century. Future research should aim to expand on previous work and investigate mixing regimes at a truly global scale (such as across climatic gradients, including perennially ice-covered lakes), including both freshwater and saline lakes.

\section{[H1] Implications for lake ecosystems}

Effects of climate change on lake ecosystems have been observed globally, including changes in water quality associated with increases in phytoplankton biomass and shifts in community

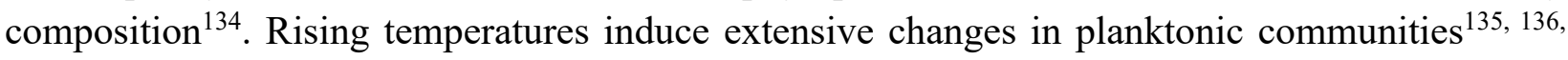
${ }^{137}$, such as shifts toward increased cyanobacteria populations and greater toxin production ${ }^{138,}$, 139, ${ }^{140}$. Unprecedented cyanobacterial blooms have been identified even in remote lakes, driven by earlier ice-out, incomplete mixing, early stratification onset and subsequent increased internal nutrient loading ${ }^{141}$. Earlier onset of phytoplankton blooms has been observed in many lakes, including advances of 30 days from 2003 to 2017 for Lake Taihu, China ${ }^{142}$ and of 28.5 days from the period 1984-1994 to 2007-2017 for Lake Köyliönjärvi, Finland ${ }^{143}$. Increases in chlorophyll and cyanobacteria are also often associated with a lowering of water level in many lakes and reservoirs, sometimes accompanied by regime shifts from clear to turbid waters that are not necessarily reversible ${ }^{144}$. In some lakes, increased stratification due to climate change results in declines in algal biomass, which adversely impact fish yields ${ }^{145,146}$. Also observed is a general shift toward lower food quality from both interna $1^{147}$ and external sources ${ }^{148}$ that will likely have consequences for lake food webs. Changing water temperatures further influence metabolism, biodiversity, and species invasions ${ }^{149}$.

Changes in winter conditions and precipitation have a range of consequences. For example, altering the duration, timing, and condition of lake ice will affect biogeochemical cycling, community composition, algal biomass ${ }^{150}$, food web dynamics, and gas emissions, ${ }_{151}{ }^{152}$ with similar consequences from permafrost thaw ${ }^{153}$. Precipitation and snowmelt are among the major factors that affect nutrient and dissolved organic matter (DOM) availability in lakes. In conjunction with other environmental changes, wetter climates will lead to 'browner' lakes from terrestrial inputs of $\mathrm{DOM}^{131,132}$, which has implications for carbon cycling and anoxia ${ }^{154}$, species invasions ${ }^{155}$, the persistence of pathogens ${ }^{156}$, and other ecological attributes ${ }^{157}$. Climate change in combination with browning and eutrophication [G] will alter the function and fueling of aquatic food webs ${ }^{158}$. Indirectly, climate warming also affects lake ecosystems through changes in the landscape that lead to shifts in vegetation ${ }^{159}$ or increased dust ${ }^{160}$ that can affect nutrient availability, water quality, and community composition and productivity ${ }^{161}$.

Many emerging changes in lake ecosystems are the result of complex interactions among a multitude of climatic factors, in addition to human activities and lake characteristics. The influence of climate remains persistently detectable, however, even across lakes also affected by factors such as oil and gas extraction ${ }^{162}$, forest harvest ${ }^{163,164}$ and invasive species ${ }^{164}$. Human impacts on 
terrestrial nutrient cycles are among the most prevalent interacting factors, and the combination of increases in both nutrient inputs and temperature could be synergistic, leading to hypoxic conditions and influencing community structure and biodiversity ${ }^{165,166}$ and the frequency, intensity, extent, and duration of harmful algal blooms ${ }^{138,167}$. Negative effects of legacy conditions can be magnified in the presence of warming, supporting proposed synergisms between chemical pollution and other stressors ${ }^{168}$. Lake responses are not necessarily regionally synchronous, as morphometric characteristics are known to drive trajectories of warming ${ }^{10}$ and ice $\operatorname{loss}^{7}$, and lake depth has also been linked to community responses ${ }^{163}$. In general, climate change will likely amplify the negative effects of eutrophication and other stressors to lake ecosystems ${ }^{169,170}$.

\section{[H1] Future directions}

Climate change has unquestionably altered lakes worldwide. Spatial and temporal variability notwithstanding, we expect the observed, long-term trends discussed here to not only continue, but in some cases accelerate. Specifically, lake ice cover will likely decrease and LSWT will increase as a result of projected changes in air temperature and earlier stratification onset, and there will be increases in lake evaporation due to warming of surface waters, loss of lake ice, and an earlier start to the evaporation season. Lake levels will likely decrease in some regions but increase in others (depending on glacier retreat and precipitation and ET trends, among other factors), and lake mixing will occur less frequently due to a general strengthening of thermal stratification. Interactions between climate and other stressors will likely lead to some unexpected, non-linear ecological responses, further complicating the development of effective management strategies.

While our understanding of physical lake responses to global climate change has improved markedly in recent decades, the scientific literature addresses in detail only a small proportion of lakes worldwide. Further improvements in remotely sensing (especially of smaller lakes) and insitu data will be essential for advancing a comprehensive global understanding of lake processes and their responses to climate change. Specifically, previous observational campaigns have focused on various lakes and time periods, often with inconsistent observational protocols and techniques, thus limiting the effectiveness of a global-scale quantification of lake variables and their interactions. Future efforts investigating lake responses to climate change need to be grounded in

547 One effort in this direction is the ongoing European Space Agency Climate Change Initiative for Lakes (CCI Lakes), which coordinates a range of remote sensing techniques to address the lake ECVs identified by GCOS. Further expansion of remotely sensed data using multiple sensors could help fill data gaps and obtain consistent observational constraints for lakes worldwide. An important aspect of efforts such as CCI Lakes is that they focus on maximizing the benefit of legacy Earth observations made over past decades, as well as developing better observational capabilities from current and prospective missions. State-of-the-art observational datasets presently provide measurement time series of lake state for a few hundred lakes. Based on current and historic sensors, records of combined temperature, reflectance, and optically derived lake-ice state observations for roughly 10,000 lakes may prove tractable with improved remote sensing methods. 
558

559

560

561

562

563

564

565

566

567

568

569

570

571

572

573

574

575

576

577

578

579

580

581

582

583

584

585

586

587

588

589

590

591

592

593

594

595

596

597

598

599

In addition to optically derived lake-ice observations from missions such as MODIS, all-weather remote sensing capability is available in microwave domains, with synthetic aperture radar (SAR) techniques enabling lake ice determination at resolutions on the order of $30 \mathrm{~m}$. Ongoing missions (such as Sentinel 1 and the RADARSAT Constellation Mission) greatly increase the routine temporal coverage, enabling the interactions of lake ice and climatic variability to be quantified more comprehensively in the future. Future satellite missions in development for expansion of the European Copernicus Space Programme will expand lake observations. An upcoming microwave mission will enable all-weather day and night observations of LSWT $^{171}$ and ice cover at, respectively, $<15 \mathrm{~km}$ and $<5 \mathrm{~km}$ resolution, for large lakes. An optical and infrared mission will enable accurate LSWT observation at $<50 \mathrm{~m}$ resolution under clear skies, expanding observability to water bodies with linear dimension $<300 \mathrm{~m}$. In addition, the altimeters on-board Sentinel $3 \mathrm{~A}$ and $3 \mathrm{~B}$ will further improve our ability to measure water levels, especially for lakes of a few kilometres in extent ${ }^{172}$, leading to more accurate mapping of surface water storage.

Satellite observations must be combined with highly spatiotemporally-resolved in situ measurements from buoys, field sampling programs, long-term monitoring networks, and paleolimnological datasets, as well as advanced, in-situ technology such as autonomous buoys, gliders, and drones. Specifically, in-situ measurements are essential for observing lake processes below the water surface (such as stratification and mixing), to improve understanding of complex air-water energy fluxes (such as evaporation), and to maintain long-term perspectives that began prior to the advent of satellites and regardless of weather conditions that adversely impact satellite measurements. Furthermore, calibration between in situ measurements and remote sensing observations is needed for many ecological variables (such as algal biomass), as we lack a complete understanding of how to measure many ecological variables accurately using remote sensing.

However, in situ lake data which are not carefully indexed and stored can become nearly invisible to scientists and other potential users. These so-called "dark data" are likely to remain underutilized and eventually lost. Therefore, further understanding of lake responses to past climate change calls for renewed efforts to rescue, scan, and digitize historical data, and to overcome impediments to data sharing and delivery. In situ observational campaigns across diverse lakes will yield the greatest science return when resulting datasets are documented and made open ${ }^{10,173}$.

Observations should be combined with predictions from statistical and process-based lake models ${ }^{174}$, particularly to help elucidate mechanisms and to disentangle anthropogenic and natural drivers. Data assimilation, in which satellite and in situ observations are systematically combined with numerical models, provides a range of methodologies to quantify both the time-evolution of the state of a lake and the lake-model parameters (as in ref. 175). Also, the new modelling paradigm known as process-guided deep learning ${ }^{176}$, which aims to integrate process understanding from lake models into advanced machine learning modelling techniques, will provide substantial improvements in our predictive ability of lake responses to climate change. Improved modelling techniques could allow background variability within the climate system to be more effectively disentangled from anthropogenic climate change. The proposed advancements in lake research 
600

601

602

603

604

605

606

607

608

609

610

611

612

613

614

615

616

617

618

619

620

621

622

623

624

625

626

627

628

629

630

631

632

633

634

635

636

637

638

639

640

641

642

provide strong promise for improved measurements and modeling of lake processes and, as a result, greater prospects for understanding and anticipating future lake responses to climate change.

\section{References}

1. Verpoorter, C., Kutser, T., Seekell, D.A. \& Tranvik, L.J. A global inventory of lakes based on high-resolution satellite imagery. Geophys. Res. Lett. 41, 6396-6402 (2014)

2. Gleick, P.H. Water and conflict: Fresh water resources and international security. International Security 18, 79-112 (1993)

3. Abell, R. et al. Freshwater ecoregions of the world: A new map of biogeographic units for freshwater biodiversity conservation. BioScience 58, 403-414 (2008)

4. Rinke, K. et al. Ecosystem services from inland waters and their aquatic ecosystems In: Schröter, M., Bonn, A., Klotz, S., Seppelt, R. \& Baessler, C. (eds.) Atlas of ecosystem services: drivers, risks, and societal responses Springer International Publishing, Cham, p. 191-192 (2019)

5. United Nations. Resolution adopted by the General Assembly on 25 September 2015. 21 October, 2015 A/Res/70/1 (2016)

6. Adrian, R. et al. Lakes as sentinels of climate change. Limnol. Oceanogr. 54, 2283-2297 (2009)

7. Sharma, S. et al. Widespread loss of lake ice around the Northern Hemisphere in a warming world. Nat. Clim. Change 9, 227-231 (2019)

8. Rodell, M. et al. Emerging trends in global freshwater availability. Nature 557, 651-659 (2018)

9. Wang, W. et al. Global lake evaporation accelerated by changes in surface energy allocation in a warmer climate. Nat. Geosci. 11, 410-414 (2018)

10. O'Reilly, C.M. et al. Rapid and highly variable warming of lake surface waters around the globe. Geophys. Res. Lett. 42, 10773-10781 (2015)

11. Woolway, R.I. \& Merchant, C.J. Worldwide alteration of lake mixing regimes in response to climate change. Nat. Geosci. 12, 271-276 (2019)

12. Pekel, J.-F., Cottam, A., Gorelick, N. \& Belward, A.S. High-resolution mapping of global surface water and its long-term changes. Nature 540, 418-422 (2016)

13. Walsh, S.E., Vavrus, S.J., Foley, J.A., Fisher, V.A., Wynne, R.H. \& Lenters, J.D. Global patterns of lake ice phenology and climate model simulations and observations. J. Geophys. Res. Atmos. 103, 28825-28837 (1998)

14. Magnuson, J.J. et al. Historical Trends in Lake and River Ice Cover in the Northern Hemisphere, Science 289, 1743-1746 (2000)

15. Brown, L.C. \& Duguay, C.R. The response and role of ice cover in lake-climate Interactions. Prog. Phys. Geog. 34, 671-704 (2010)

16. Vavrus, S. J., Wynne, R.H. \& Foley, J.A. Measuring the sensitivity of southern Wisconsin lake ice to climate variations and lake depth using a numerical model. Limnol. Oceanogr. 41, 822-831 (1996)

17. Spence, C., Blanken, P.D., Lenters, J.D. \& Hedstrom, N. The importance of spring and autumn atmospheric conditions for the evaporation regime of Lake Superior. J. Hydromet. 14, $1647-1658$ (2013)

18. Jensen, O.P. et al. Spatial analysis of ice phenology trends across the Laurentian Great Lakes region during a recent warming period. Limnol. Oceanogr. 52, 2013-2026 (2007) 
19. Nöges, P. \& Nöges, T. Weak trends in ice phenology of Estonian large lakes despite significant warming trends. Hydrobiologia 731, 5-18 (2014)

20. Williams, G., Layman, K. \& Stefan, H.G. Dependence of lake ice covers on climatic, geographic and bathymetric variables. Cold Reg. Sci. Technol. 40, 145-164 (2004)

21. Magee, M.R. \& Wu, C.H. Effects of changing climate on ice cover in three morphometrically different lakes. Hydrol. Process. 31, 308-323 (2017)

22. Palecki, M.A. \& Barry, R.G. Freeze-up and break-up of lakes as an index of temperature changes during the transition seasons: A case study for Finland. J. Clim. Appl. Meteorol. 25, 893-902 (1986)

23. Duguay, C.R., Prowse, T.D., Bonsal, B.R., Brown, R.D., Lacroix, M.P. \& Ménard, P. Recent trends in Canadian lake ice cover. Hydrol. Process. 20, 781-801 (2006)

24. Weyhenmeyer, G.A., Livingstone, D.M., Meili, M., Jensen, O., Benson, B. \& Magnuson, J.J. Large geographical differences in the sensitivity of ice-covered lakes and rivers in the Northern Hemisphere to temperature changes. Glob. Change Biol. 17, 268-275 (2011)

25. Arp, C.D., Jones, B.M. \& Gross, G. Recent lake ice-out phenology within and among lake districts of Alaska, U.S.A. Limnol. Oceanogr. 58, 213-228 (2013)

26. Benson, B.J. et al. Extreme events, trends, and variability in Northern Hemisphere lake-ice phenology (1855-2005). Clim. Change 112, 299-323 (2012)

27. Sharma, S., Magnuson, J.J., Mendoza, G. \& Carpenter, S.R. Influences of local weather, large-scale climatic drivers, and the ca. 11 year solar cycle on lake ice breakup dates; 19052004. Clim. Change 118, 857-870 (2013)

28. Jakkila, J. et al. Radiation transfer and heat budget during the ice season in Lake Paajarvi, Finland. Aquat. Ecol. 43, 681-692 (2009)

29. Kouraev, A.V., Semovski, S.V., Shimaraev, Mognard, N.M., Legrésy, B. \& Rémy, F. The ice regime of Lake Baikal from historical and satellite data: Relationship to air temperature, dynamical, and other factors. Limnol. Oceanogr. 52, 1268-1286 (2007)

30. Kirillin, G. et al. Physics of seasonally ice-covered lakes: a review. Aquat. Sci. 74, 659-682 (2012)

31. Brown, L.C. \& Duguay, C.R. The fate of lake ice in the North American Arctic. Cryosphere 5, 869-892 (2011)

32. Dibike,Y., Prowse, T., Saloranta, T. \& Ahmed, R. Response of Northern Hemisphere lakeice cover and lake-water thermal structure patterns to a changing climate. Hydrol. Process. 25, 2942-2953 (2011)

33. Sharma, S., Magnuson, J.J., Batt, R.D., Winslow, L.A., Korhonen, J. \& Aono, Y. Direct observations of ice seasonality reveal changes in climate over the past 320-570 years. Sci. Rep. 6, 25061 (2016)

34. Robertson, D.M., Wynne, R.H. \& Chang, W.Y.B. Influence of El Niño on lake and river ice cover in the Northern Hemisphere from 1900 to 1995. Internationale Vereinigung für theoretische und angewandte Limnologie: Verhandlungen 27, 2784-2788 (2000)

35. Van Cleave, K., Lenters, J.D., Wang, J., \& Verhamme, E.M. A regime shift in Lake Superior ice cover, evaporation, and water temperature following the warm El Ninõ winter of 1997-1998. Limnol. Oceanogr. 59, 1889-1898 (2014) 
36. Lopez, L.S., Hewitt, B.A. \& Sharma, S. Reaching a break point: How is climate change influencing the timing of ice break-up in lakes across the Northern Hemisphere. Limnol. Oceanogr. 64, 2621-2631 (2019)

37. Higuchi, K., Huang, J. \& Amir, S.A. Wavelet Characterization of the North Atlantic Oscillation Variation and Its Relationship to the North Atlantic Sea Surface Temperature. Int. J. Climatol. 19, 1119-1129 (1999)

38. Li, J. et al. Interdecadal modulation of El Niño amplitude during the past millennium. Nat. Clim. Change 1, 114-118 (2011)

39. Bai, X., Wang, J., Sellinger, C. Clites, A. \& Assel, R. Interannual variability of Great Lakes ice cover and its relationship to NAO and ENSO. J. Geophys. Res. 117, doi:10.1029/2010JC006932 (2012)

40. Edinger, J.E., Duttweiler, D.W. \& Geyer, J.C. The response of water temperature to meteorological conditions. Water Resour. Res. 4, 1137-1143 (1968)

41. Lenters, J.D., Kratz, T.K. \& Bowser, C.J. Effects of climate variability on lake evaporation: Results from a long-term energy budget study of Sparkling Lake, northern Wisconsin (USA). J. Hydrol. 308, 168-195 (2005)

42. Austin, J.A. \& Colman, S.M. Lake Superior summer water temperatures are increasing more rapidly than regional air temperatures: a positive ice-albedo feedback. Geophys. Res. Lett. 34, L06604, doi:10.1029/2006GL029021 (2007)

43. Woolway, R.I. \& Merchant, C.J. Amplified surface temperature response of cold, deep lakes to inter-annual air temperature variability. Sci. Rep. 7, 4130, doi:10.1038/s41598-01704058-0 (2017)

44. Schmid, M. \& Köster, O. Excess warming of a Central European lake by solar brightening. Water Resour. Res. 52, 8103-8116 (2016)

45. Zhong, Y. Notaro, M., Vavrus, S.J. \& Foster, M.J. Recent accelerated warming of the Laurentian Great Lakes: Physical drivers. Limnol. Oceanogr. 61, 1762-1786 (2016)

46. Woolway, R.I. et al. Northern Hemisphere atmospheric stilling accelerated lake thermal responses to climate change. Geophys. Res. Lett. 46, 11983-11992 (2019)

47. Vinnå, L.R., Wuest, A., Zappa, M., Fink, G. \& Bouffard, D. Tributaries affect the thermal response of lakes to climate change. Hydrol. Earth Syst. Sci. 22, 31-51 (2018)

48. Rose, K.C., Winslow, L.A., Read, J.S. \& Hansen, G.J.A. Climate-induced warming of lakes can be either amplified or suppressed by trends in water clarity. Limnol. Oceanogr. Lett. 1, 4453 (2016)

49. Pilla, R.M. et al. Browning-related decreases in water transparency lead to long-term increases in surface water temperature and thermal stratification in two small lakes. J. Geophys. Res. Biogeo. 123, 1651-1665 (2018)

50. Screen, J.A. \& Simmonds, I. The central role of diminishing sea ice in recent arctic temperature amplification. Nature 464, 1334-1337 (2010)

51. Stuecker, M.F. et al. Polar amplification dominated by local forcing and feedbacks. Nat. Clim. Change 8, 1076-1081 (2018)

52. Schneider, P. \& Hook, S.J. Space observations of inland water bodies show rapid surface warming since 1985. Geophys. Res. Lett. 37, L22405 (2010) 
53. Groisman, P.Y., Karl, T.R. \& Knight, R.W. Observed impact of snow cover on the heat balance and the rise of continental spring temperatures. Science 263, 198-200 (1994)

54. Goose, H., et al. Quantifying climate feedbacks in polar regions. Nat. Comm. 9(1919) (2018)

55. Ye, X., Anderson, E.J., Chu, P.Y., Huang, C. \& Wue, P. Impact of water mixing and ice formation on the warming of Lake Superior: A model-guided mechanism study. Limnol. Oceanogr. 64, 558-574 (2018)

56. Mishra, V., Cherkauer, K.A. \& Bowling, L.C. Changing thermal dynamics of lakes in the Great Lakes region: Role of ice cover feedbacks. Glob. Plan Change 75, 155-172 (2011)

57. Woolway, R.I. \& Merchant, C.J. Intralake heterogeneity of thermal responses to climate change: A study of large northern hemisphere lakes. J. Geophys. Res. Atmos. 123, 3087-3098 (2018)

58. Winslow, L.A., Reed, J.S., Hansen, G.J.A., Rose, K.C. \& Robertson, D.M. Seasonality of change: Summer warming rates do not fully represent effects of climate change on lake temperatures. Limnol. Oceanogr. 62, 2168-2178 (2017)

59. Woolway, R.I. et al. Warming of Central European lakes and their response to the 1980s climate regime shift. Clim. Change 142, 505-520 (2017)

60. Maberly, S.C. et al. Global lake thermal regions shift under climate change. Nat. Comm. 11:1232 (2020)

61. Schindler, D.W. The cumulative effects of climate warming and other human stresses on Canadian freshwaters in the new millennium. Can. J. Fish. Aquat. Sci. 58, 18-29 (2001)

62. Riveros-Iregui, D.A., Lenters, J.D., Peake, C.S., Ong, J.B., Healy, N.C. \& Zlotnik, V.A. Evaporation from a shallow, saline lake in the Nebraska Sandhills: Energy balance drivers of seasonal and interannual variability. J. Hydrol. 553, 172-187 (2017)

63. MacIntyre, S., Fram, J.P., Kushner, P.J., Bettez, N.D., O’Brien, W.J., Hobbie, J.E. \& Kling, G.W. Climate-related variations in mixing dynamics in an Alaskan arctic lake. Limnol. Oceanogr. 54(6, part 2), 2401-2417 (2009)

64. Zhan, S., Song, C., Wang, J., Sheng, Y. \& Quan, J. A global assessment of terrestrial evapotranspiration increase due to surface water area change. Earth's Future 7, 266-282 (2019)

65. Salhotra, A. Effect of salinity and ionic composition on evaporation: analysis of Dead Sea evaporation pans. Water Resour. Res. 21, 1336-1344 (1985)

66. Fujisaki-Manome, A. et al. Turbulent heat fluxes during an extreme lake-effect snow event. J. Hydrometeorol. 18, 3145-3163 (2017)

67. Friedrich, K. et al. Reservoir evaporation in the western United States: Current science, challenges, and future needs. Bull. Amer. Met. Soc. 99, 167-187 (2017)

68. Trenberth, K.E., Fasullo, J.T. \& Kiehl, J.T. Earth's global energy budget. B. Am. Meteorol. Soc. 90, 311-323 (2009)

69. Wild, M., Folini, D., Schär, C., Loeb, N., Dutton, E.G. \& König-Langlo, G. The global energy balance from a surface perspective. Clim. Dyn. 40, 3107-3134 (2013)

70. Verburg, P. \& Antenucci, J.P. Persistent unstable atmospheric boundary layer enhances sensible and latent heat loss in a tropical great lake: Lake Tanganyika. J. Geophys. Res. 115, D11109, doi:10.1029/2009JD012839 (2010) 
71. Woolway, R.I. et al. Geographic and temporal variations in turbulent heat loss from lakes: A global analysis across 45 lakes. Limnol. Oceanogr. 63, 2436-2449 (2018)

72. Blanken, P.D., Spence, C., Hedstrom, N. \& Lenters, J.D. Evaporation from Lake Superior: 1. Physical controls and processes. J. Great Lakes Res. 37(4), 707-716 (2011)

73. McVicar, T.R. et al. Global review and synthesis of trends in observed terrestrial near surface wind speeds: Implications for evaporation. J. Hydrol. 416-417, 182-205 (2012)

74. Watras, C.J., Morrison, K.A. \& Rubsam, J.L. Effect of DOC on evaporation from small Wisconsin lakes. J. Hydrol. 540, 162-175 (2016)

75. Wild, M. Global dimming and brightening: A review. J. Geophys. Res. 114, D00D16, doi:10.1029/2008JD011470 (2009)

76. Roderick M.L. \& Farquhar, G.D. The cause of decreased pan evaporation over the past 50 years. Science 298, 1410-1411 (2002)

77. Zeng, Z. et al. A reversal in global terrestrial stilling and its implications for wind energy production. Nat. Clim. Change 9, 979-985 (2019)

78. Desai, A.R., Austin, J.A., Bennington, V. \& McKinley, G.A. Stronger winds over a large lake in response to weakening air-to-lake temperature gradient. Nat. Geosci. 2, 855-858 (2009)

79. Roderick, M.L., Sun, F., Lim, W.H. \& Farquhar, G.D. A general framework for understanding the response of the water cycle to global warming over land and ocean. Hydrol. Earth Syst. Sci. 18, 1575-1589 (2014)

80. Sherwood, S. \& Fu, Q. A drier future? Science 343, 737-739 (2014)

81. Liu, H., Blanken, P.D., Weidinger, T., Nordbo, A. \& Vesala, T. Variability in cold front activities modulating cool-season evaporation from a southern inland water in the USA. Environ. Res. Lett. 6(024022) (2011)

82. Watras, C.J., et al. Decadal oscillation of lakes and aquifers in the upper Great Lakes region of North America: Hydroclimatic implications. Geophys. Res. Lett. 41(2), 456-462 (2014)

83. Held, I.M. \& Soden, B.J. Robust responses of the hydrological cycle to global warming. $J$. Clim. 19(21), 5686-5699 (2006)

84. Trenberth, K.E. Changes in precipitation with climate change. Clim. Research 47, 123-138 (2011)

85. Greve, P., Orlowsky, B., Mueller, B., Sheffield, J., Reichstein, M. \& Seneviratne, S.I. Global assessment of trends in wetting and drying over land. Nat. Geosci. 7, 716-721 (2014)

86. Donat, M.G., Lowry, A.L., Alexander, L.V., O’Gorman, P.A. \& Maher, N. More extreme precipitation in the world's dry and wet regions. Nat. Clim. Change 6, 508-513 (2016)

87. Liu, C. \& Allen, R.P. Observed and simulated precipitation responses in wet and dry regions 1850-2100. Env. Res. Lett. 8, 034002 (2013)

88. Byrne, M.P. \& O'Gorman, P.A. The Response of Precipitation Minus Evapotranspiration to Climate Warming: Why the "Wet-Get-Wetter, Dry-Get-Drier" Scaling Does Not Hold over Land. J. Climate 28, 8078-8092 (2015)

89. Chadwick, R., Good, P., Martin, G. \& Rowell, D.P. Large rainfall changes consistently projected over substantial areas of tropical land. Nat. Clim. Change 6, 177-181 (2015)

90. Greve, P. \& Seneviratne, S.I. Assessment of future changes in water availability and aridity. Geophys. Res. Lett. 42, 5493-5499, doi:10.1002/2015GL064127 (2015) 
91. Huang, J., Yu, H., Guan, X., Wang, G. \& Guo, R. Accelerated dryland expansion under climate change. Nat. Clim. Change 6, 166-171 (2016)

92. Boehlert, B., Solomon, S. \& Strzepek, K.M. Water under a Changing and Uncertain Climate: Lessons from Climate Model Ensembles. J. Climate 28, 9561-9582 (2015)

93. Kumar, S., Allan, R.P., Zwiers, Lawrence, D.M. \& Dirmeyer, P.A. Revisiting trends in wetness and dryness in the presence of internal climate variability and water limitations over land. Geophys. Res. Lett. 42, 10867-10875, doi:10.1002/ 2015GL066858 (2015)

94. Markonis, Y., Papalexiou, S.M., Matinkova, M. \& Hanel, M. Assessment of Water Cycle Intensification Over Land using a Multisource Global Gridded Precipitation Data Set. J. Geophys. Res. Atmos. 124, 11175-11187 (2019)

95. Brutsaert, W. \& Parlange, M.B. Hydrologic cycle explains the evaporation paradox. Nature 396, 30 (1998)

96. Westra, S., Alexander, L.V. \& Zwiers, F.W. Global Increasing Trends in Annual Maximum Daily Precipitation. J. Climate 26, 3904-3918 (2013)

97. Gronewold, A.D. \& Rood, R.B. Recent water level changes across Earth's largest lake system and implications for future variability. J. Great Lakes Res. 45, 1-3 (2019)

98. Notaro, M., Bennington, V. \& Lofgren, B. Dynamical downscaling-based projections of Great Lakes water levels. J. Clim. 28, 9721-9745 (2015)

99. Busker, T., et al. A global lake and reservoir volume analysis using a surface water dataset and surface altimetry. Hydrol. Earth Syst. Sci. 23, 669-690 (2019)

100. Hegerl, G.C. et al. Challenges in quantifying changes in the global water cycle. Bull. Am. Meteorol. Soc. 96, 1097-115 (2015)

101. Zhang, G. et al. Extensive and drastically different alpine lake changes on Asia's high plateaus during the past four decades. Geophys. Res. Lett. 44, 252-260 (2017)

102. Zhang, G. et al. Lake volume and groundwater storage variations in Tibetan Plateau's endorheic basin. Geophys. Res. Lett. 44, 5550-5560 (2017)

103. Huang, L., Liu, J., Shao, Q. \& Liu, R. Changing inland lakes responding to climate warming in Northeastern Tibetan Plateau. Clim. Change 109, 479-502 (2011)

104. Ma, R. et al. A half-century of changes in China's lakes: Global warming or human influence? Geophys. Res. Lett. 37, doi:10.1029/2010GL045514 (2010)

105. Wang, J. et al. Recent global decline in endorheic basin water storages. Nat. Geosci. 11, 926-932 (2018)

106. Smith, L.C., Sheng, Y., MacDonald, G.M. \& Hinzman, L.D. Disappearing Arctic lakes. Science 308, 1429 (2005)

107. Van Huissteden, J., Berrittella, C., Parmentier, F.J.W., Mi, Y., Maximov, T.C. \& Dolman, A.J. Methane emissions from permafrost thaw lakes limited by lake drainage. Nat. Clim. Change 1, 119-123 (2011)

108. Micklin, P. The past, present, and future Aral Sea. Lakes Reserv. Res. Manag. 15, 193-213 (2010)

109. Small, E.E., Giorgi, F., Sloan, L.C. \& Hostetler, S. The effects of Desiccation and climatic change on the hydrology of the Aral Sea. J. Clim. 14, 300-322 (2001)

110. Satgé, F. et al. Role of Climate Variability and Human Activity on Poopó Lake Droughts between 1990 and 2015 Assessed Using Remote Sensing Data. Remote Sens. 9(3), 218 (2017) 
111. Lei, Y. et al. Extreme lake level changes on the Tibetan Plateau Associated with the 2015/2016 El Ninõ. Geophys. Res. Lett. 46, 5889-5898 (2019)

112. Wang, S.Y., Gillies, R.R., Jin, J. \& Hipps, L.E. Coherence between the Great Salt Lake level and the Pacific quasi-decadal oscillation. J. Clim. 23, 2161-2177 (2010)

113. Benson, L.V. et al. Correlation of Late-Pleistocene Lake-Level Oscillations in Mono Lake, California, with North Atlantic Climate Events. Quat. Res. 49, 1-10 (1998)

114. Marchant, R., Mumbi, C., Behera, S. \& Yamagata, T. The Indian Ocean dipole - the unsung driver of climatic variability in East Africa. Afr. J. Ecol. 45, 4-16 (2007)

115. Awange, J.L., Ogalo, L., Bae, K-H., Were, P., Omondi, P., Moute, P. \& Omullo, M. Falling Lake Victoria water levels: Is climate a contributing factor? Clim. Change 89(1-2), 281-297 (2008)

116. Muller, M. Cape Town's drought: don't blame climate change. Nature 59, 174-176 (2018)

117. Angel, J.R. \& Kunkel, K.E. The response of Great Lakes water levels to future climate scenarios with an emphasis on Lake Michigan-Huron. J. Great Lakes Res. 36, 51-58 (2010)

118. Malsy, M., Aus der Beek, T., Eisner, S. \& Flörke, M. Climate change impacts on Central Asian water resources. Adv. Geosci. 32, 77-83 (2012)

119. MacKay, M. \& Seglenieks, F. On the simulation of Laurentian Great Lakes water levels under projections of global climate change. Clim. Change 117, 55-67 (2013)

120. Lewis, W.M. Jr. A revised classification of lakes based on mixing. Can. J. Fish. Aquat. Sci. 40, 1779-1787 (1983)

121. Kirillin, G. Modeling the impact of global warming on water temperature and seasonal mixing regimes in small temperate lakes. Boreal Environ. Res. 15, 279-293 (2010)

122. Shatwell, T., Thiery, W. \& Kirillin, G. Future projections of temperature and mixing regime of European temperate lakes. Hydrol. Earth Syst. Sci. 23, 1533-1551 (2019)

123. Ficker, H., Luger, M. \& Gassner, H. From dimictic to monomictic: Empirical evidence of thermal regime transitions in three deep alpine lakes in Austria induced by climate change. Freshwater Biol. 62, 1335-1345 (2017)

124. Mueller, D. R., Van Hove, P., Antoniades, D., Jeffries, M.O. \& Vincent, W.F. High Arctic lakes as sentinel ecosystems: Cascading regime shifts in climate, ice cover, and mixing. Limnol. Oceanogr. 54, 2371-2385 (2009)

125. Woolway, R.I. et al. Substantial increase in minimum lake surface temperature under climate change. Clim. Change 155, 81 (2019)

126. Yankova, Y., Neuenschwander, S., Köster, O. \& Posch, T. Abrupt stop of deep water turnover with lake warming: Drastic consequences for algal primary producers. Sci. Rep. 7: 13770 (2017)

127. Weyhenmeyer, G.A., Westöö, A.K. \& Willén, E. Increasingly ice-free winters and their effects on water quality in Sweden's largest lakes. In: Nõges T. et al. (eds) European Large Lakes Ecosystem changes and their ecological and socioeconomic impacts. Developments in Hydrobiology, vol 199. Springer, Dordrecht (2007)

128. Woolway, R.I., Meinson, P., Nõges, P., Jones, I.D. \& Laas, A. Atmospheric stilling leads to prolonged thermal stratification in a large shallow polymictic lake. Clim. Change 141, 759$773(2017)$ 
129. Shatwell, T., Adrian, R. \& Kirillin, G. Planktonic events may cause polymictic-dimictic regime shifts in temperate lakes. Sci. Rep. 6, 24361 (2016)

130. Williamson, C. E. et al. Lakes as sensors in the landscape: Optical metrics as scalable sentinel responses to climate change. Limnol. Oceanogr., 59(3), 840-850 (2014)

131. de Wit, H.A. et al. Current browning of surface waters will be further promoted by wetter climate. Environ. Sci. Techn. Lett. 3, 430-435, doi:10.1021/acs.estlett.6b00396 (2016)

132. Meyer-Jacob, C. et al. The browning and re-browning of lakes: Divergent lake-water organic carbon trends linked to acid deposition and climate change. Sci. Rep. 9, 16676 (2019)

133. Rogozin, D.Y. et al. Disturbance of meromixis in saline Lake Shira (Siberia, Russia): Possible reasons and ecosystem response. Limnologica 66, 12-23 (2017)

134. Ho, J.C., Michalak, A.M. \& Pahlevan, N. Widespread global increase in intense lake phytoplankton blooms since the 1980s. Nature 574, 667-670 doi:10.1038/s41586-019-1648-7 (2019)

135. da Silva, C.F.M., Torgan, L.C. \& Schneck, F. Temperature and surface runoff affect the community of periphytic diatoms and have distinct effects on functional groups: evidence of a mesocosms experiment. Hydrobiologia 839, 37-50 (2019)

136. Urrutia-Cordero, P. et al. Phytoplankton diversity loss along a gradient of future warming and brownification in freshwater mesocosms. Freshwater Biol. 62, 1869-1878, doi:10.1111/fwb.13027 (2017)

137. Fey, S.B., Mertens, A.N., Beversdorf, L.J., McMahon, K.D. \& Cottingham, K.L. Recognizing cross-ecosystem responses to changing temperatures: soil warming impacts pelagic food webs. Oikos 124, 1473-1481, doi:10.1111/oik.01939 (2015)

138. Huisman, J. et al. Cyanobacterial blooms. Nat. Rev. Microbiol. 16, 471-483 (2018)

139. Urrutia-Cordero, P., Ekvall, M.K. \& Hansson, L.A. Local food web management increases resilience and buffers against global change effects on freshwaters. Sci. Rep. 6, doi:10.1038/srep29542 (2016)

140. Gallina, N., Beniston, M. \& Jacquet, S. Estimating future cyanobacterial occurrence and importance in lakes: a case study with Planktothrix rubescens in Lake Geneva. Aquat. Sci. 79, 249-263, doi:10.1007/s00027-016-0494-z (2017)

141. Favot, E.J., Rühland, K.M., DeSellas, A.M., Paterson, A.M. \& Smol, J.P. Climate variability promotes unprecedented cyanobacterial blooms in a remote, oligotrophic Ontario lake: evidence from paleolimnology. J. Paleolimnol. 62, 31-52 (2019)

142. Shi, K. et al. Phenology of Phytoplankton Blooms in a Trophic Lake Observed from LongTerm MODIS Data. Environ. Sci. Technol. 53, 2324-2331 (2019)

143. Maeda, E.E. et al. Temporal patterns of phytoplankton phenology across high latitude lakes unveiled by long-term time series of satellite data. Remote Sens. Environ. 221, 609-620, doi:10.1016/j.rse.2018.12.006 (2019)

144. Jeppesen, E. et al. Ecological impacts of global warming and water abstraction on lakes and reservoirs due to changes in water level and related changes in salinity. Hydrobiologia 750, 201-227, doi:10.1007/s10750-014-2169-x (2015)

145. O'Reilly, C.M., Alin, S.R., Plisnier, P-D., Cohen, A.S. \& McKee, B.A. Climate change decreases aquatic ecosystem productivity of Lake Tanganyika, Africa. Nature 424, 766-768 (2003) 
146. Verburg, P., Hecky, R. E. \& Kling, H. Ecological consequences of a century of warming in Lake Tanganyika. Science 301, 505-507, doi:10.1126/science.1084846 (2003)

147. Galloway, A.W.E. \& Winder, M. Partitioning the Relative Importance of Phylogeny and Environmental Conditions on Phytoplankton Fatty Acids. Plos One 10, doi:10.1371/journal.pone.0130053 (2015)

148. Verbeek, L., Gall, A., Hillebrand, H. \& Striebel, M. Warming and oligotrophication cause shifts in freshwater phytoplankton communities. Glob. Change Biol. 24, 4532-4543, doi:10.1111/gcb.14337 (2018)

149. Hesselschwerdt, J. \& Wantzen, K.M. Global warming may lower thermal barriers against invasive species in freshwater ecosystems - A study from Lake Constance. Sci. Tot. Env. 645, 44-50, doi:10.1016/j.scitotenv.2018.07.078 (2018)

150. Obryk, M.K. et al. Responses of Antarctic Marine and Freshwater Ecosystems to Changing Ice Conditions. Bioscience 66, 864-879, doi:10.1093/biosci/biw109 (2016)

151. Saros, J.E. et al. Arctic climate shifts drive rapid ecosystem responses across the West Greenland landscape. Environ. Res. Lett. 14, doi:10.1088/1748-9326/ab2928 (2019)

152. Hampton, S.E. et al. Ecology under lake ice. Ecol. Lett. 20, 98-111, doi:10.1111/ele.12699 (2017)

153. Pastick, N.J. et al. Spatiotemporal remote sensing of ecosystem change and causation across Alaska. Glob. Change Biol. 25, 1171-1189, doi:10.1111/gcb.14279 (2019)

154. Brothers, S. et al. A feedback loop links brownification and anoxia in a temperate, shallow lake. Limnol. Oceanogr. 59, 1388-1398 (2014)

155. Mormul, R.P., Ahlgren, J., Ekvall, M.K., Hansson, L-A. \& Brönmark, C. Water brownification may increase the invasibility of a submerged non-native macrophyte. Biol. Invasions 14, 2091-2099, doi:10.1007/s10530-012-0216-y (2012)

156. Williamson, C.E. et al. Climate change-induced increases in precipitation are reducing the potential for solar ultraviolet radiation to inactivate pathogens in surface waters. Sci. Rep. 7, doi:10.1038/s41598-017-13392-2 (2017).

157. Williamson, C.E. et al. Ecological consequences of long-term browning in lakes. Sci. Rep. 5, 18666 https://doi.org/10.1038/srep18666 (2015)

158. Hayden, B. et al. From clear lakes to murky waters - tracing the functional response of highlatitude lake communities to concurrent 'greening' and 'browning'. Ecol. Lett. 22, 807-816, doi:10.1111/ele.13238 (2019)

159. Finstad, A.G. et al. From greening to browning: Catchment vegetation development and reduced S-deposition promote organic carbon load on decadal time scales in Nordic lakes. Sci. Rep. 6, 31944 (2016)

160. Jimenez, L., Ruhland, K.M., Jeziorski, A., Smol, J.P. \& Perez-Martinez, C. Climate change and Saharan dust drive recent cladoceran and primary production changes in remote alpine lakes of Sierra Nevada, Spain. Glob. Change Biol. 24, E139-E158, doi:10.1111/gcb.13878 (2018)

161. Symons, C.C., Schulhof, M.A., Cavalheri, H.B. \& Shurin, J.B. Antagonistic effects of temperature and dissolved organic carbon on fish growth in California mountain lakes. Oecologia 189, 231-241 (2019) 
981

982

983

984

985

986

987

988

989

990

991

992

993

994

995

996

997

998

999

1000

1001

1002

1003

1004

1005

1006

1007

1008

1009

1010

1011

1012

1013

1014

1015

1016

1017

1018

1019

1020

162. Coleman, K.A. et al. Assessing long-term changes in aquatic ecosystems near a small conventional oil and gas operation in the Cameron Hills, southern Northwest Territories, Canada. Fund. Appl. Limnol. 192, 181-197 (2019)

163. Levesque, D., Pinel-Alloul, B., Methot, G. \& Steedman, R. Effects of Climate, Limnological Features and Watershed Clearcut Logging on Long-Term Variation in Zooplankton Communities of Boreal Shield Lakes. Water 9, doi:10.3390/w9100733 (2017)

164. Gutowsky, L.F.G., Giacomini, H.C., de Kerchkove, D.T., McCormick, D. \& Chu, C. Quantifying multiple pressure interactions affecting populations of a recreationally and commercially important freshwater fish. Glob. Change Biol. 25, 1049-1062, doi:10.1111/gcb.14556 (2019)

165. Biswas, S.R., Vogt, R.J. \& Sharma, S. Projected compositional shifts and loss of ecosystem services in freshwater fish communities under climate change scenarios. Hydrobiologia 799, 135-149, doi:10.1007/s10750-017-3208-1 (2017)

166. Smith, S.D.P. et al. Evidence for interactions among environmental stressors in the Laurentian Great Lakes. Ecol. Indic. 101, 203-211 (2019)

167. Brooks, B.W. et al. Are Harmful Algal Blooms Becoming the Greatest Inland Water Quality Threat to Public Health and Aquatic Ecosystems? Environ. Toxicol. Chem. 35, 6-13 (2016)

168. Cambronero, M.C. et al. Predictability of the impact of multiple stressors on the keystone species Daphnia. Sci. Rep. 8, doi:10.1038/s41598-018-35861-y (2018)

169. Greaver, T.L. et al. Key ecological responses to nitrogen are altered by climate change. Nat Clim. Change 6, 836-843, doi:10.1038/nclimate3088 (2016)

170. Collingsworth, P.D. et al. Climate change as a long-term stressor for the fisheries of the Laurentian Great Lakes of North America. Rev. Fish. Biol. Fisheries 27, 363-391 (2017)

171. Kilic, L. et al. Expected performances of the Copernicus Imaging Microwave Radiometer (CIMR) for an all-weather and high spatial resolution estimation of ocean and sea ice parameters. J. Geophys. Res. Oceans 123, 7564-7580 (2018)

172. Cretaux, J.-F. et al. Lake volume monitoring from space. Surv. Geophys. 37, 269-305 (2016)

173. Piwowar, H.A. \& Vision, T.J. Data reuse and the open data citation advantage. PeerJ 1:e175 doi:10.7717/peerj.175 (2013)

174. Bruce, L.C. et al. A multi-lake comparative analysis of the General Lake Model (GLM): Stress-testing across a global observatory network. Env. Modell. Soft. 102, 274-291 (2018)

175. Zwart, J.A. et al. Improving estimates and forecasts of lake carbon dynamics using data assimilation. Limnol. Oceanogr. Methods 17, 97-111 (2019)

176. Read, J.S. et al. Process-guided deep learning predictions of lake water temperature. Water Resour. Res. 55, 9173-9190 doi:10.1029/2019WR024922 (2019)

177. Carrea, L. \& Merchant C.J. GloboLakes: Lake Surface Water Temperature (LSWT) v4.0 (1995-2016). Centre for Environmental Data Analysis, 29 March 2019. doi:10.5285/76a29c5b55204b66a40308fc2ba9cdb3 (2019) 
1021

1022

1023

1024

1025

1026

1027

1028

1029

1030

1031

1032

1033

1034

1035

1036

1037

1038

1039

1040

1041

1042

1043

1044

1045

1046

1047

1048

1049

1050

1051

1052

1053

1054

1055

1056

1057

1058

1059

1060

1061

1062

\section{Highlighted references}

1 - O'Reilly, C.M. et al. Rapid and highly variable warming of lake surface waters around the globe. Geophys. Res. Lett. 42, 10773-10781 (2015)

Significance: First global-scale analysis of satellite-derived and in-situ lake surface temperature responses to climate change, showing rapid and widespread warming of lakes from 1985 to 2009.

2 - Pekel, J.-F., Cottam, A., Gorelick, N. \& Belward, A.S. High-resolution mapping of global surface water and its long-term changes. Nature 540, 418-422 (2016)

Significance: Investigated the temporal and spatial variations in the availability of surface water worldwide since 1984, as well as its response to climate change and human activities.

3 - Sharma, S. et al. Widespread loss of lake ice around the Northern Hemisphere in a warming world. Nat. Clim. Change 9, 227-231 (2019)

Significance: Demonstrated that lake ice cover will severely diminish during the $21^{\text {st }}$ century throughout the Northern Hemisphere, with many lakes no longer experiencing ice cover in winter.

4 - Woolway, R.I. \& Merchant, C.J. Worldwide alteration of lake mixing regimes in response to climate change. Nat. Geosci. 12, 271-276 (2019)

Significance: Projected that climate change will result in the worldwide alteration of lake mixing regimes by the end of the $21^{\text {st }}$ century, which will have large implications for lake ecosystems.

5 - Wang, W. et al. Global lake evaporation accelerated by changes in surface energy allocation in a warmer climate. Nat. Geosci. 11, 410-414 (2018)

Significance: First study to demonstrate that lake evaporation will increase worldwide during the $21^{\text {st }}$ century due to a warming of lake surface temperature and a reduction in lake ice cover.

6 - Magnuson, J.J. et al. Historical Trends in Lake and River Ice Cover in the Northern Hemisphere, Science 289, 1743-1746 (2000)

Significance: Analyzed ice cover trends from lakes and rivers around the Northern Hemisphere using over 100 years of data.

7 - Schneider, P. \& Hook, S.J. Space observations of inland water bodies show rapid surface warming since 1985. Geophys. Res. Lett. 37, L22405 (2010) 
1063 Significance: First worldwide study of surface temperature trends in the largest lakes of the 1064 world.

1065

1066

1067

1068

1069

1070

8 - Ho, J.C., Michalak, A.M. \& Pahlevan, N. Widespread global increase in intense lake phytoplankton blooms since the 1980s. Nature 574, 667-670 doi:10.1038/s41586-019-1648-7 (2019)

1071

1072

10739 - Wang, J. et al. Recent global decline in endorheic basin water storages. Nat. Geosci. 11, 926$1074932(2018 b)$

1075

1076

Significance: Used satellite observations and hydrological modelling to demonstrate that the 1077 1078

1079 global endorheic system experienced a widespread water loss during the start of the 21 st century.

1080

1081

1082

10 - Rodell, M. et al. Emerging trends in global freshwater availability. Nature 557, 651-659 (2018)

Significance: Quantified trends and characterised the drivers of change in terrestrial water storage observed by the Gravity Recovery and Climate Experiment (GRACE) satellites. 
1083

1084

1085

1086

1087

1088

1089

1090

1091

1092

1093

1094

1095

1096

1097

1098

1099

1100

1101

1102

1103

1104

1105

1106

1107

1108

1109

1110

1111

1112

1113

1114

1115

1116

1117

\section{Acknowledgements}

RIW received funding from the European Union's Horizon 2020 research and innovation programme under the Marie Skłodowska-Curie grant agreement No. 791812. BMK received support from the Belmont Forum, BiodivERsA, and the German Research Foundation through the LimnoScenES project (AD 91/22-1). SS thanks John Magnuson, Gesa Weyhenmeyer, Johanna Korhonen, Yasuyuki Aono, Lars Rudstam, Nikolay Granin, and Kevin Blagrave for their assistance updating the lake ice phenology records. JDL thanks Martin Dokulil, Katrin Teubner, Pius Niederhauser, and David Livingstone for their assistance updating the LSWT records. JDL was supported in part by the Wisconsin Department of Natural Resources grant no. I02E01485 (New Innovations in Lake Monitoring). This work benefited from participation in GLEON (Global Lake Ecological Observatory Network). The Cumbrian Lakes monitoring scheme, which provided lake temperature data from Windermere, is currently supported by the Natural Environment Research Council award number NE/R016429/1 as part of the UK-SCaPE programme delivering National Capability.

\section{Contributions}

RIW initiated and led the project. This review is the result of a collective effort from all authors, with leadership on different sections as follows: SS led lake ice; RIW led lake temperatures and mixing regimes; JDL led evaporation and wetting-drying; BMK led lake level and extent, CMO led ecosystem impacts, and CJM led the remote sensing summary. RIW, SS, JDL, and BMK compiled data. RIW, SS, JDL, and BMK led the design of visualizations. All authors contributed to the introduction and future directions, and participated in discussions, revisions, and the final production of this manuscript.

\section{Competing interests}

The authors do not have any competing financial or non-financial interests to declare.

\section{Peer review information}

Nature Reviews Earth \& Environment thanks [Referee\#1 name], [Referee\#2 name] and the other, anonymous, reviewer(s) for their contribution to the peer review of this work.

\section{Publisher's note}

Springer Nature remains neutral with regard to jurisdictional claims in published maps and institutional affiliations. 
1118 Related links

1119 European Space Agency Climate Change Initiative for Lakes: http://cci.esa.int/lakes

1120 USDA G-REALM project: https://ipad.fas.usda.gov/cropexplorer/global_reservoir/

1121 Hydroweb: http://hydroweb.theia-land.fr/

1122 World Meteorological Organization Global Climate Observing System Essential Climate

1123 Variables: https:/public.wmo.int/en/programmes/global-climate-observing-system/essential-

1124 climate-variables

1125 Global Lake Ecological Observatory Network: https://gleon.org/

1126

1127

1128 


\section{Figures}

\section{Climate change}
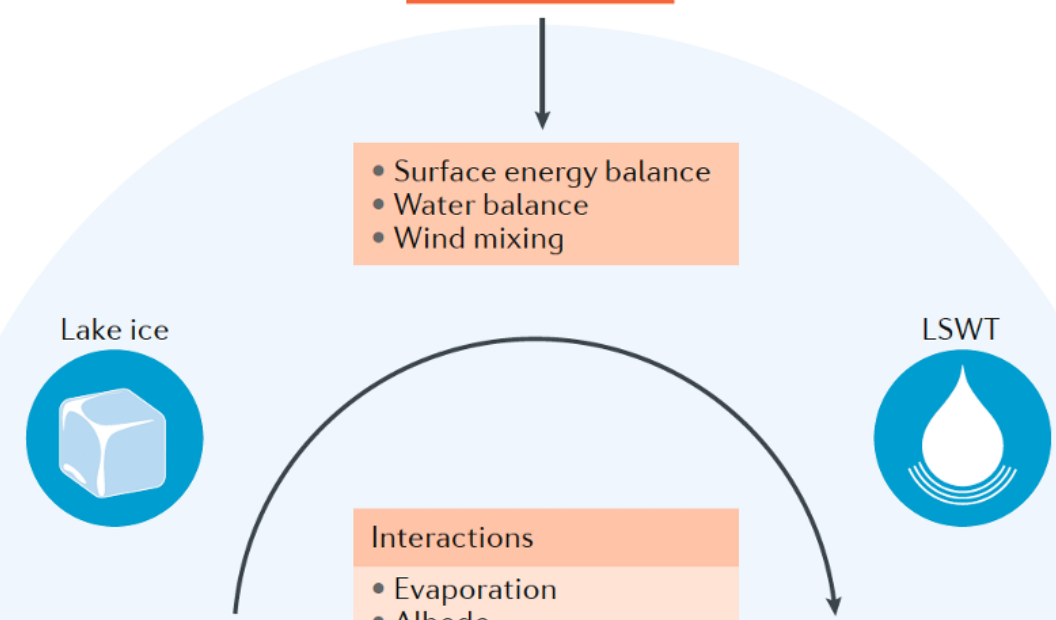

- Albedo
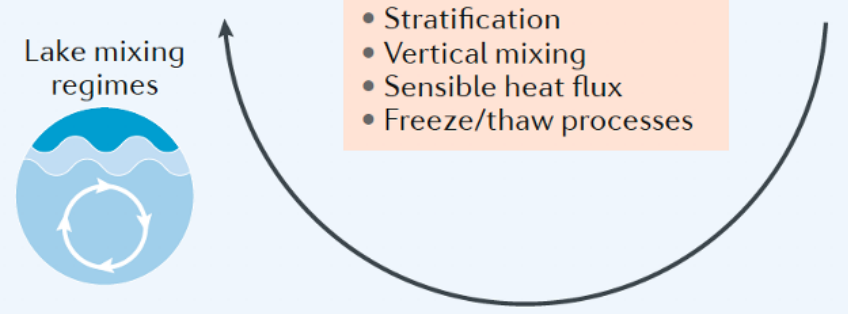

Lake area and water level

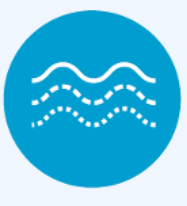

Figure 1 | Lakes in a changing climate. Essential lake variables, their response to climate change and how they interact with one another. For example, decreasing ice cover, increasing water temperature, and altered lake mixing regimes will influence evaporation rates, with subsequent alterations in lake water levels and extent. Climate-induced changes in these key physical lake variables will influence lake productivity and consequently have widespread implications for the ecosystem services that lakes provide. 

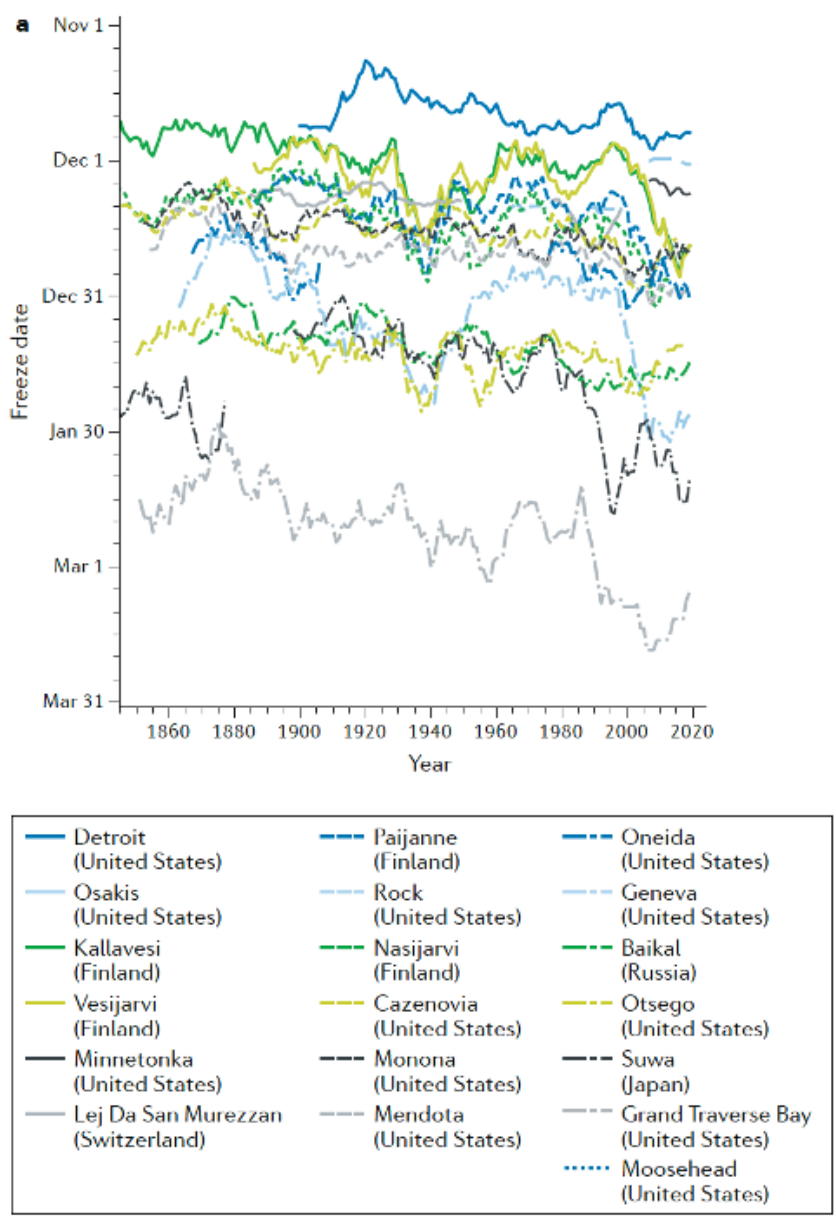

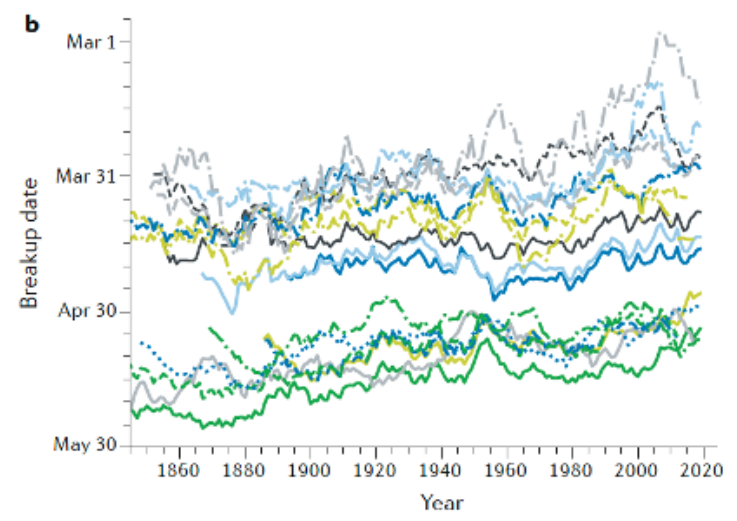

c

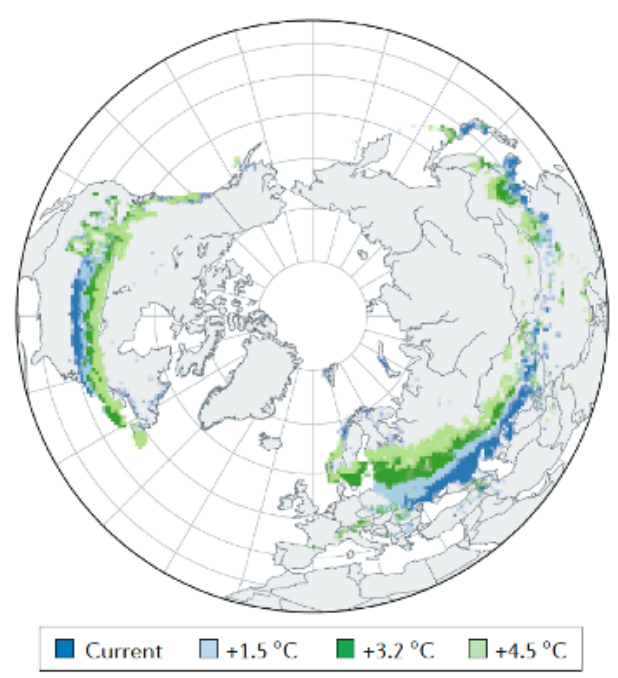

Figure 2 | Lake ice cover responses to climate change. $\mathbf{A} \mid$ Ice freeze and $\mathbf{B} \mid$ breakup dates from selected Northern Hemisphere lakes from 1846 to 2019, updated from ref. 14. On average, these lakes are freezing 11.6 days later and breaking up 8.1 days earlier. C| Projections of intermittent ice cover (defined as a lake not experiencing ice cover every winter) for different scenarios of climate warming 7 . Lakes shown in dark blue are the 14,800 lakes that are currently estimated to experience intermittent winter ice cover. Lakes forecasted to experience intermittent winter ice cover with an air temperature increase of $1.5^{\circ} \mathrm{C}$ (light blue), $3.2^{\circ} \mathrm{C}$ (dark green), and $4.5^{\circ} \mathrm{C}$ (light green) are shown. 

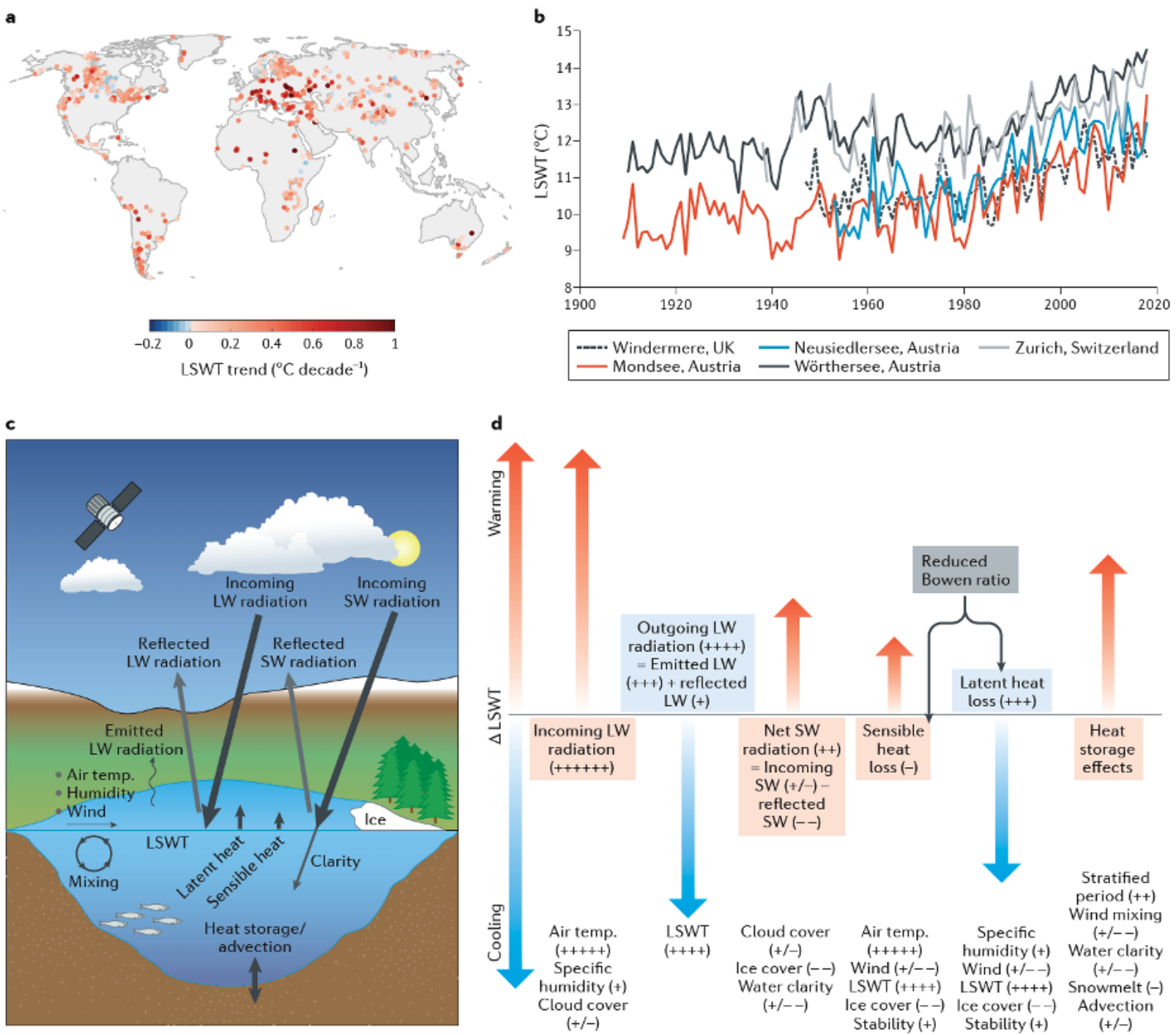
$(+/-)$

Figure 3 | Lake surface water temperatures under climate change. A| Worldwide satellitederived warm-season lake surface water temperature (LSWT) trends from 1996 to 2018 (ref. 177). B | Long-term annually averaged LSWTs in five lakes. C| Lake surface energy budget and associated atmospheric and in-lake drivers that can influence LSWT. Although both latent and sensible heat fluxes can act as either negative or positive contributions to the lake heat budget (thereby cooling or warming the lake, respectively), they are generally directed positively away from the lake, causing a general cooling effect. $\mathbf{D} \mid$ The qualitative and approximate quantitative changes in meteorological forcing, lake surface energy budget components, and LSWT that are anticipated to occur as a result of climate change. Changes are estimated for an "average" lake at the global scale and would vary across latitudes and scales. Meteorological forcings that affect each energy budget component are listed at the bottom (along with LWST, which affects emitted longwave radiation), and symbols are included to indicate anticipated positive $(+)$ or negative (-) climate trends associated with each variable. The number of symbols denotes the combined assessment of the magnitude and confidence in each trend. Some variables have mixed and/or uncertain trends (shown as $+/-$, for example). The size of the vertical arrows illustrates the expected 
1165 LSWT response to each of the changing energy balance components, indicating warming or 1166 cooling of the lake surface. LW: longwave; SW: shortwave 

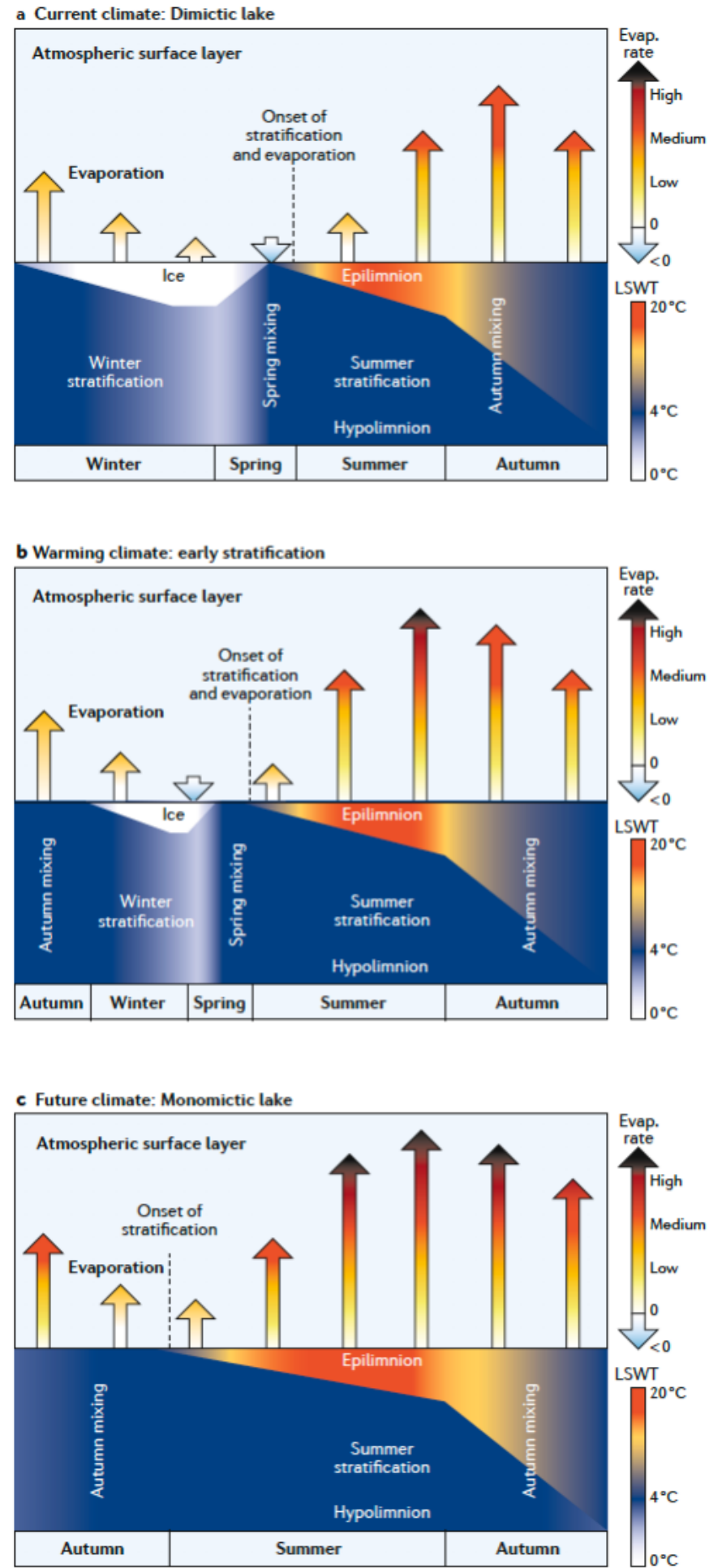

Figure 4 | Lake evaporation response to climate change. Anticipated response of a cold, dimictic moderately deep lake in the mid-latitudes to climate change, including effects on ice cover, lake surface water temperature (LSWT), evaporation, and mixing regime. Progression is shown from the current state (a), to a warm climate with earlier summer stratification (b), and eventually a very warm climate in which all winter stratification and spring mixing are lost (c). Here, the lake "winter" is defined as the period from ice-on to the beginning of ice melt, followed by spring mixing, with summer starting at the onset of stratification and lasting until the onset of autumn 
1175 mixing. The largest initial increases in lake evaporation are anticipated in association with earlier

1176 summer onset, but with eventual increases in evaporation throughout all seasons as the lake 1177 continues to warm. The seasonal timing of maximum evaporation would be earlier for shallower 1178 lakes and later for deeper lakes. Evaporation during the ice-covered periods denotes the effects of 1179 sublimation and fractional ice coverage (such as open-water leads), with condensation occurring 1180 around ice-off. 

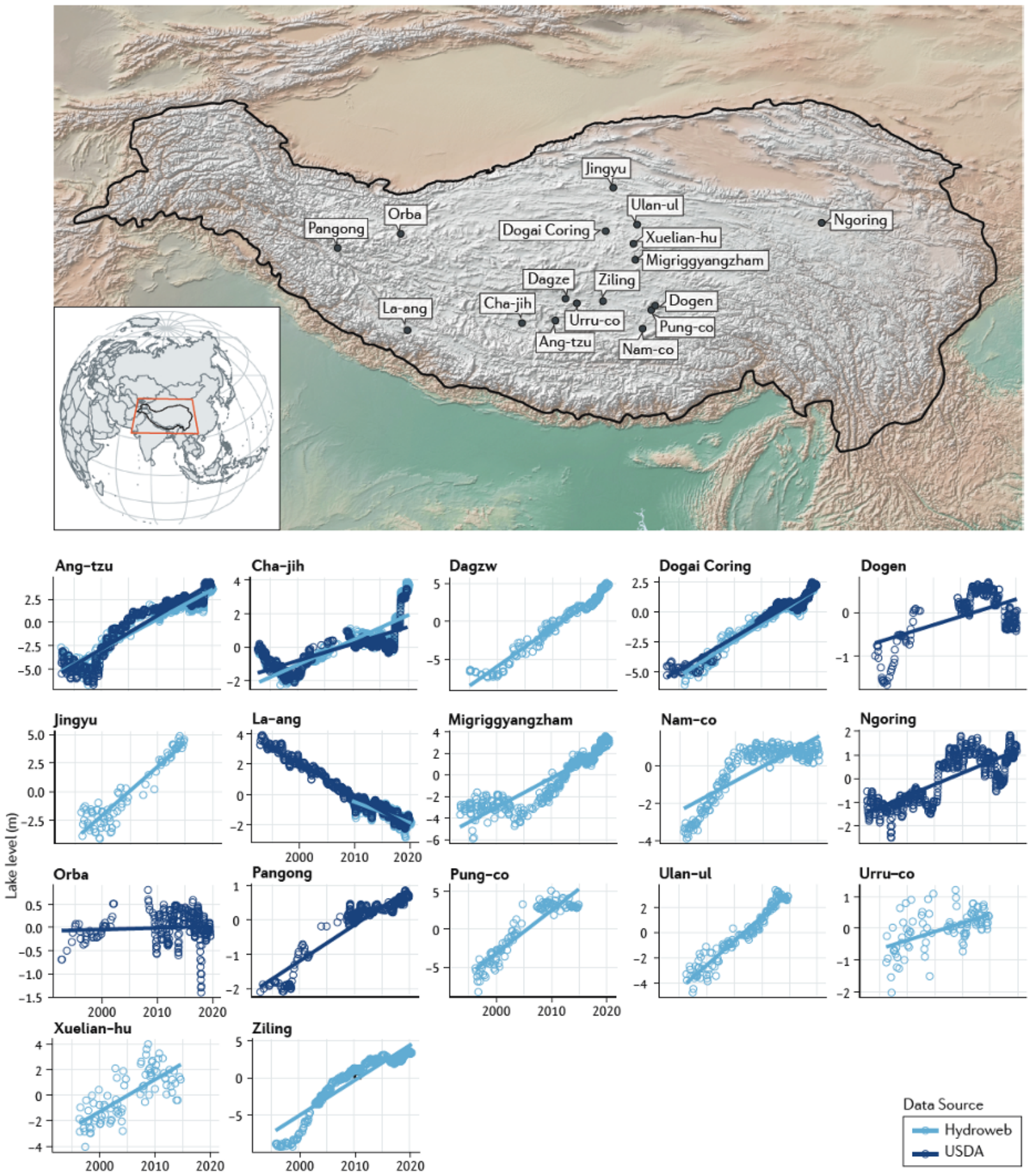

Data Source

$\cong$ Hydroweb

$\simeq$ USDA

1183 Figure 5 | Lake level changes for 17 lakes on the Tibetan Plateau. Examples of water level changes for 17 lakes on the Tibetan Plateau. Various lakes in this region are expanding or contracting due to changes in precipitation, ice cover, glacier and permafrost melt, as well as human alterations. These changes are partially attributable to climate change driven shifts in precipitation and glacier-melt. Data are courtesy of the USDA G-REALM project and the Hydroweb database (both datasets shown when available). 

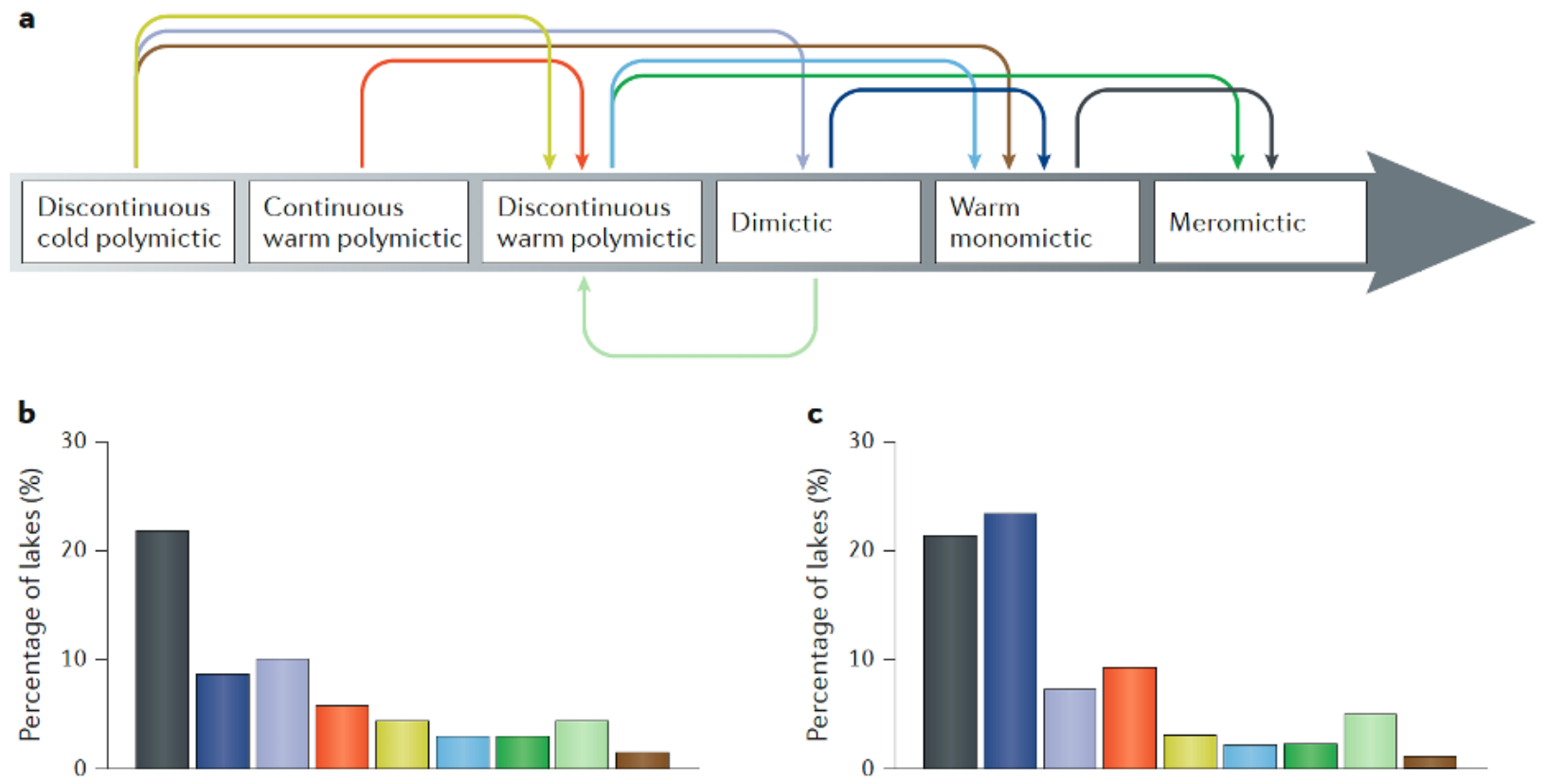

Warm Mono. - Meromictic

Dimictic - Warm Mono.

Disc. Cold Poly. - Dimictic

Cont. Warm Poly, - Disc. Warm Poly.

Disc. Col. Poly. - Disc. Warm Poly.

Figure 6 | Lake mixing regime alterations due to projected $21^{\text {st }}$ century climate change. The mixing regime alterations relate to simulated changes in lake mixing regimes between 1985-2005 and 2080-2100 (a) using a lake model forced with low (RCP 2.6) (b) and high (RCP 6.0) (c) greenhouse gas concentration scenario. A widespread decrease in winter ice cover and an increase in lake surface temperatures will modify lake mixing regimes, typically shifting lakes to the right along the polymictic-dimictic-monomictic-oligomictic-meromictic continuum. As lakes mix less frequently in response to climate change, some of the most common anticipated mixing regime alterations include a shift from dimictic to monomictic and from monomictic to meromictic. Data from Woolway and Merchant (2019). 


\section{[b1] Lake mixing regimes}

1204 [H3] Polymictic: Lakes that are permanently (continuous polymictic) or frequently (discontinuous polymictic) mixed, often due to their shallow depth. Can be sub-categorised as cold polymictic if they experience winter ice cover, or warm polymictic if they do not freeze.

[H3] Dimictic: Experiencing two mixing events per year, one typically following the summer stratified period and the other following the inversely stratified winter period.

[H3] Monomictic: Experiencing one vertical mixing event per year, typically in winter. Can be sub-categorised as cold monomictic if they experience winter ice cover or warm monomictic if 1211 they do not freeze.

1212 [H3] Oligomictic: Persistently stratified in most years, yet mix fully in others

1213 [H3] Meromictic: Persistently stratified, often due to their immense depths or due to the presence 1214 of a chemical gradient.

1215
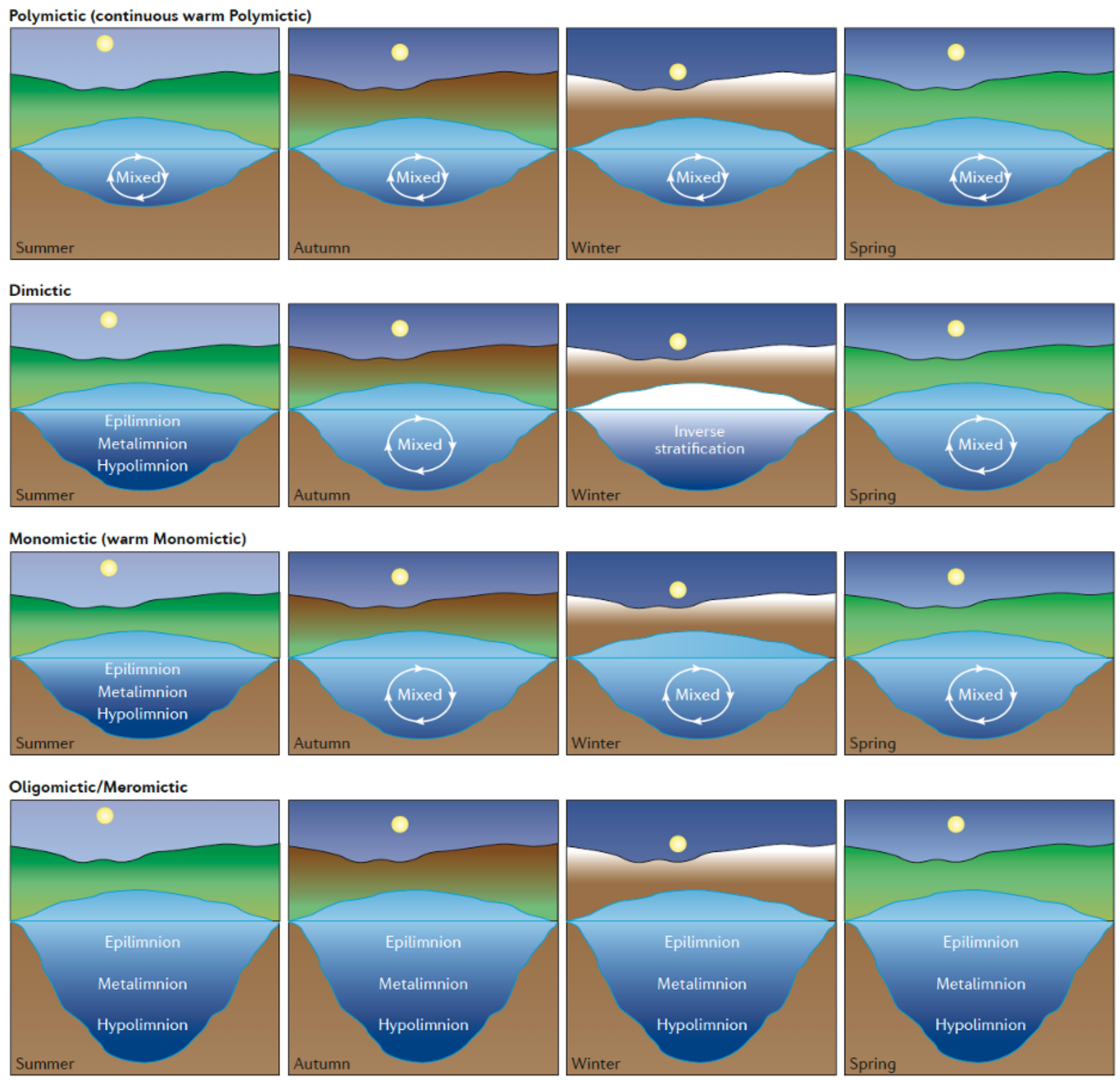


\section{Glossary of specialist terms}

1219 Bowen ratio: The ratio of sensible to latent heat fluxes

1220 Fetch: The area of a lake surface over which the wind blows in an essentially constant direction

1221 Albedo: The fraction of light reflected from a surface, expressed as the ratio of outgoing to

1222 incoming solar radiation

1223 Advection: The lateral transport of heat, water, or other material into or out of a lake

1224 Brightening: Increase in the receipt of solar radiation at the earth's surface due to long-term

1225 changes in cloud cover or aerosols

1226 Dimming: Decrease in the receipt of solar radiation at the earth's surface due to long-term

1227 changes in cloud cover or aerosols

1228 Evapotranspiration: The process of water vapor transport from the Earth's surface to the atmosphere, represented as the total evaporated water from soil, water, and other wet surfaces, 1230 and transpiration from plants

1231 Browning: An increase in the yellow-brown colour of lake surface waters, caused mainly by an 1232 increase in dissolved organic carbon concentrations

1233 Eutrophication: The enrichment of a water body with nutrients often resulting in excessive algae 1234 growth

1235 Total runoff: Surface runoff plus groundwater recharge

1236 Thermokarst lakes: Lakes formed by thawing ice-rich permafrost

\section{Table of contents summary}

1241 Climate change affects lakes worldwide and is predicted to continue to alter lake ice cover, surface temperature, evaporation rates, water levels, and mixing regimes. This Review discusses recent and expected lake responses to climate change and looks towards future research 